\title{
THE MISSING WEALTH OF NATIONS: ARE EUROPE AND THE U.S. NET DEBTORS OR NET CREDITORS?
}

\author{
Gabriel ZuCMAN \\ Paris School of Economics*
}

February 25, 2013 ${ }^{\dagger}$

\begin{abstract}
This paper shows that official statistics substantially underestimate the net foreign asset positions of rich countries because they fail to capture most of the assets held by households in offshore tax havens. Drawing on a unique Swiss dataset and exploiting systematic anomalies in countries' portfolio investment positions, I find that around $8 \%$ of the global financial wealth of households is held in tax havens, three-quarters of which goes unrecorded. On the basis of plausible assumptions, accounting for unrecorded assets turns the eurozone, officially the world's second largest net debtor, into a net creditor. It also reduces the U.S. net debt significantly. The results shed new light on global imbalances and challenge the widespread view that, after a decade of poor-to-rich capital flows, external assets are now in poor countries and debts in rich countries. I provide concrete proposals to improve international statistics.
\end{abstract}

Keywords: Tax havens, International investment positions, Global imbalances JEL classifications: F32, H26, H87.

*48 boulevard Jourdan, 75014 Paris, France, zucman@pse.ens.fr. A detailed Appendix is available online.

${ }^{\dagger}$ I am very grateful to my advisor Thomas Piketty for his continuous support and guidance. I thank the editor (Robert Barro), five anonymous referees, Jean-Edouard Colliard, Mihir Desai, Nicolas Frémeaux, Lucie Gadenne, Pierre-Olivier Gourinchas, Philip Lane, Gian Maria Milesi-Ferretti, Richard Sylla, Daniel Waldenström, Edward Wolff, and participants at numerous seminars. Paul Farello, Christopher Gohrband, Steve Landefeld, and Robert Yuskavage from the Bureau of Economic Analysis also provided helpful comments. Part of this paper was drafted while I was visiting NYU; I am grateful to Jess Benhabib who made this visit possible. 


\section{Introduction}

There are two puzzles in international investment statistics. The first is a set of statistical anomalies. At the global level, liabilities tend to exceed assets: the world as a whole is a net debtor (Lane and Milesi-Ferretti, 2007). Similarly, the global balance of payments shows that more investment income is paid than received each year. Since the problem was identified in the 1970s, the International Monetary Fund has commissioned a number of reports to investigate its causes, and national statistical agencies have put considerable resources into improving their data. Yet despite a great deal of progress, large anomalies remain; many European securities, in particular, have no identifiable owner (Milesi-Ferretti, Strobbe, and Tamirisa, 2010).

The second puzzle is a theoretical challenge. Since the latter half of the 1990s, capital has been flowing from poor to rich countries. As a result, the rich world now appears to be a sizeable net debtor in the official data, dragged down by the U.S. and Europe. While the literature has put forward possible explanations for the U.S. net debt and the rise in China's assets, ${ }^{1}$ the negative net positions of Europe and the overall rich world remain largely unexplained. Despite this, many observers have grown accustomed to the view that external assets are now in poor countries and debts in rich countries. In the public debate, the view that "China owns the world" has become particularly popular. Should it be correct, the implications for policymaking and open-economy modeling would be far-reaching.

My paper challenges this view. The negative net foreign asset position of the rich world, I argue, is an illusion caused by tax havens. International statistics fail to capture most of the assets held by households through tax havens: they overlook the portfolios of equities, bonds, and mutual fund shares that households own via banks in Switzerland and other countries with strict bank secrecy rules. This coverage gap explains many of the long-standing anomalies in global data. My computations find that around $8 \%$

\footnotetext{
${ }^{1}$ See Dooley, Folkerts-Landau, and Garber (2003), Bernanke (2005), Dollar and Kraay (2006), Engel and Rogers (2006), Caballero, Farhi, and Gourinchas (2008), Mendoza, Rios-Rull, and Quadrini (2009), Carroll and Jeanne (2009), Ma and Haiwen (2009), Obstfeld, Shambaugh, and Taylor (2010), Aguiar and Amador (2011), Song, Storesletten, and Zilibotti (2011), and Alfaro, Kalemli-Ozcan, and Volosovych (2011) among others.
} 
of households' financial wealth is held through tax havens, three-quarters of which goes unrecorded. This stock of unrecorded assets is double the recorded net debt of the rich world (Figure I). Since a body of evidence suggests that most of the wealth in tax havens belongs to residents of rich countries, accounting for it turns the rich world into a net creditor. Despite a decade of global imbalances, therefore, external wealth is still probably in rich countries overall: China does not own the world yet. Back in the 1980s-1990s the rich world had a large positive net position; over the last decade it has eaten some of its claims away; but today poor countries are still repaying their debts to advanced economies.

These findings have direct implications for core issues in international macroeconomics. On the basis of plausible assumptions, accounting for the wealth in tax havens turns the eurozone, officially the world's second largest net debtor, into a net creditor. It also improves the U.S. net position. Now, the net foreign asset position is a key state variable in dynamic macroeconomic models. Accurate net positions are essential to assess the merits of the different views put forward on the causes of global imbalances and they are important to monitor financial stability. A large body of literature has questioned the sustainability of global imbalances. ${ }^{2}$ If indeed the net positions of Europe and the U.S. are higher than in the official statistics, the required international adjustment is smaller than commonly thought. Domestic imbalances and public finance issues may be more serious today for rich countries than global imbalances: rich countries taken as a whole are richer than we think, but some of their wealthiest residents hide part of their assets in tax havens, which contributes to making governments poor. So far, tax havens have been ignored by the literature that studies the evolution of top income shares around the world (Atkinson, Piketty, and Saez, 2011). ${ }^{3}$ My findings, therefore, also have implications for this strand of research: my macro-based estimate of the funds held through tax havens

\footnotetext{
${ }^{2}$ See Obstfeld and Rogoff (2005), Blanchard, Giavazzi, and Sa (2005), Gourinchas and Rey (2007a), the papers in Clarida (2007), Hausmann and Sturzenegger (2007), Curcuru, Dvorak, and Warnock (2008), and Blanchard and Milesi-Ferretti (2009) among others.

${ }^{3}$ The two exceptions are Roine and Waldenström (2009) who use anomalies in Sweden's balance of payments to approximate capital flight, and Dell, Piketty, and Saez (2007) who use Swiss tax data to put an upper bound on the amount of capital income earned in Switzerland by non-resident taxpayers. Tax data, however, are not an appropriate source in this case, because the bulk of income earned by foreigners in Switzerland does not have to be declared to Swiss tax authorities.
} 
could be used as a first step to include these funds into micro-based studies of income and wealth distributions.

The paper proceeds as follows. Section II begins with a brief primer on the activities that take place in tax havens and the statistical issues involved. Section III analyses a previously unused official dataset from the Swiss National Bank. A considerable amount of wealth is held unrecorded in Swiss accounts, and contrary to popular belief, this wealth mostly belongs to residents of rich countries. Section IV then presents a novel method to estimate the personal wealth in all the world's tax havens, using anomalies in the aggregate portfolio stock data of countries (the key source here is Lane and Milesi-Ferretti, 2007). My method is indirect and relies on data with known imperfections, so it is subject to some margin of error. Section V presents consistency and robustness checks, based on bilateral and flow data from the IMF, suggesting that the order of magnitude I find is reliable. The many datasets used in this paper all paint the same picture: households own a large amount of mutual fund shares through unrecorded accounts in tax havens. In Section VI, I propose scenarios as to how including the unrecorded assets in the statistics would affect published international investment positions. I discuss the implications for global imbalances and the uncertainties that remain. The conclusion provides concrete proposals to improve the official data. There are numerous intricacies in the financial activities of tax havens and the international statistics. The most important ones are discussed in the paper; others are detailed in a comprehensive Online Appendix.

\section{Tax Havens and Their Implications for International Statistics}

First, let's look at the basic concepts that will be used throughout the paper. A country's foreign assets and liabilities are recorded in its international investment position (IIP). The IIP is the stock equivalent of the financial account of the balance of payments: the IIP shows the stock of existing cross-border investments at the end of each year, while the balance of payments shows the yearly flow of new investments. There are three broad categories of cross-border claims: direct investments (holdings of over 10\%), portfolio 
securities (equities and bonds that do not qualify as direct investment), and other assets (mainly loans and deposits). ${ }^{4}$ At the end of 2008, as shown by Table I, securities were the largest category: they accounted for $\$ 40$ tr out of $\$ 90$ tr.

Tax havens host numerous financial activities. About $40 \%$ of the world's foreign direct investments are routed through tax havens such as the British Virgin Islands. ${ }^{5}$ Many investment funds and financial vehicles are incorporated offshore. Luxembourg is the second largest mutual fund center in the world after the U.S; a great deal of the world's money market funds are incorporated in Ireland; and most hedge funds are in the Cayman Islands. Multinational corporations routinely use tax havens for treasury operations and group insurance. Some of these activities have legitimate roles and are satisfactorily covered in the statistics. ${ }^{6}$ My paper focuses on one specific tax haven activity: personal wealth management or "private banking". This activity is present in many but not all tax havens. Leaders include countries with strict bank secrecy rules such as Switzerland, the Cayman Islands, the Bahamas, Hong Kong, Singapore, and Jersey. Banks incorporated in these countries - which are often subsidiaries of large global banks - attract foreign individuals and provide them with investment advice and services. In the IIPs of countries, the personal wealth management activities of tax havens do not affect direct investment data, slightly affect "other assets", but cause large, systematic errors for portfolio securities.

\section{II.A. How Cross-Border Securities Should be Recorded in Principle}

To see what errors occur in portfolio data, denote $A_{i j}$ the amount of securities issued by country $j$, owned by residents of country $i \neq j$. To measure $A_{i j}$, the data collection system of each country $i$ covers some agents directly and others indirectly (IMF, 2002). Financial corporations such as banks, investment funds, and insurance companies, are

\footnotetext{
${ }^{4}$ On the asset side of official IIPs, statisticians isolate a fourth category, reserve assets, which includes the portfolio securities and other assets held by central banks. In this paper, "securities" will always include the fraction of reserve assets invested in securities.

${ }^{5}$ See data gathered by the IMF for its Coordinated Direct Investment Survey. In 2011 for instance, 30\% of India's inward direct investments came from Mauritius; 25\% of Brazils' came from the Netherlands; $60 \%$ of China's came from Hong Kong and the British Virgin Islands.

${ }^{6}$ See for instance IMF (2000).
} 
direct reporters. They provide data on their own holdings (the securities that are on their balance sheets) and on their clients' holdings (the securities that are off their balance sheets, but that they can observe). Governments and nonfinancial corporations above a certain size threshold are also direct reporters. By contrast, households are indirectly covered, for practical reasons. Their holdings are reported by financial companies. Trusts, personal wealth-holding companies, and other small nonfinancial corporations are indirectly covered as well, and I include them in the household sector. We can therefore write $A_{i j}$ as the sum of the foreign securities owned by directly covered agents $\left(a_{i j}\right)$ and households $\left(\tilde{a}_{i j}\right)$.

All types of investors entrust their securities to domestic or to foreign banks for custody. Through to the 1960s, all securities existed in the form of paper certificates that were deposited in safe places such as bank vaults. Keeping their clients' certificates safe was the custodians' job. Today, paper has been replaced by electronic records, but investors still use custodian banks as book-keepers and for other services. Let's denote the custodian's country of residence with a superscript letter:

$$
A_{i j}=\sum_{k} A_{i j}^{k}=\sum_{k}\left(a_{i j}^{k}+\tilde{a}_{i j}^{k}\right)=\underbrace{\left[a_{i j}^{i}+\tilde{a}_{i j}^{i}\right]}_{\text {onshore }}+\underbrace{\sum_{k \neq i}\left(a_{i j}^{k}+\tilde{a}_{i j}^{k}\right)}_{\text {offshore }}
$$

To fix ideas, consider a portfolio of U.S. $(j)$ equities held by a household living in France $(i)$. This portfolio can either be entrusted to a French bank - in which case we will say that it is held onshore - or to an offshore bank, say in Switzerland $(k)$.

Offshore banks provide investment advice and services just like onshore banks do. But they also provide opportunities to evade personal income taxes. In most non-haven countries, onshore banks automatically report the investment income earned by their clients to tax authorities. Such third-party reporting makes tax evasion impossible. By contrast, in tax havens with strict bank secrecy rules, banks do not generally report information. Taxes can be collected only if taxpayers self-declare their income.

International investment statistics work on the basis of the residence principle (IMF, 1993). The residence principle states that a security issued by the U.S. and held by a 
French resident through a Swiss bank must be recorded as an asset for France on the U.S. and a liability for the U.S. vis-à-vis France. The location of the custodian is irrelevant.

\section{II.B. Offshore Portfolios: A Blind Spot in Securities Statistics}

In practice, offshore custodian banks cause a blind spot in portfolio assets data. When French households entrust U.S. securities to Swiss banks, these assets $\tilde{a}_{i j}^{k}$ cannot be captured by surveying French custodians. They go completely unrecorded in the French IIP. ${ }^{7}$ This blind spot is well known among statisticians: Bertaut, Griever, and Tryon (2006, p. A67) discuss it in the context of the U.S. data reporting system, the ECB (2002, p. 8) in the context of the eurozone's.

Household offshore portfolios do not appear on the IIPs of tax havens either. To compile Switzerland's external accounts, the Swiss National Bank asks domestic banks to report on the securities that they hold in custody. Swiss bankers observe that they hold U.S. securities belonging to French residents. These securities are neither assets nor liabilities for Switzerland, so in keeping with the residence principle, they are excluded from Switzerland's position.

Household offshore portfolios, however, do appear in the liabilities of countries' IIPs. U.S. securities held by French savers are duly recorded as liabilities for the U.S. whether they are held in France or in Switzerland. Most of the securities issued by the U.S. are ultimately kept by the U.S. central securities depository, the final book-keeper where settlements take place. This centralization makes it relatively easy to estimate the amount of U.S. equities and bonds held by foreigners. (The country allocation of liabilities, however, are distorted: U.S. securities held by French savers through Switzerland are wrongly attributed to Switzerland, because seeing through the Swiss banks is not possible.)

The failure to record the offshore portfolios of households plagues countries' international data. An obvious solution would be to ask each tax haven $k$ to provide information about the portfolios held by foreign individuals through their banks, the $\tilde{a}_{i j}^{k}(k \neq i)$. No

\footnotetext{
${ }^{7}$ As Section IV.A will show, transfers of funds to tax havens are not well recorded, so that it is not possible to capture offshore portfolios by cumulating banking flows. That is why errors in portfolio positions translate into errors for the full IIP.
} 
haven, however, discloses this information. No haven, except Switzerland.

\section{Offshore Wealth in Switzerland}

Since 1998, the Swiss National Bank has published the value of the offshore portfolios in Swiss banks. A monthly survey of Swiss-domiciled custodians covers $95 \%$ of these holdings. The SNB conducts a full survey yearly. Portfolios are broken down by asset class and currency. The SNB also provides evidence as to who owns Swiss accounts. I am not aware of any other paper that uses this unique set of data to investigate the wealth held offshore. The outsized role that Switzerland plays in the offshore wealth management industry means that this one data source can do a lot to fill in the gaps in countries' portfolio assets data. This Section analyzes what we learn from the Swiss case, before attempting to compute the amount of wealth held in tax havens globally.

\section{III.A. The Level and Composition of the Offshore Fortunes in Switzerland}

The first striking result, reported in the first column of Table II, is the huge amount of offshore wealth in Swiss banks. At the end of 2008 - when global stock markets were low - foreigners held through Switzerland portfolios of foreign (i.e., non Swiss) securities worth $\Omega^{s}=\$ 1.5$ tr. $^{8}$ Once you add bank deposits (more on these below), the total offshore wealth in Swiss banks comes to more than $\$ 2 \operatorname{tr}$ - as much as China's foreign exchange reserves.

For comparison, the second column of Table II shows the value of the assets belonging to Swiss residents in Swiss banks. They are much smaller. In 2008, only one-third of all the foreign securities in the Swiss banks vaults belonged to Swiss savers - two-thirds belonged to foreigners. This pattern epitomizes what offshore financial centers do: Swiss banks essentially help foreigners invest out of Switzerland, the banks acting only as

\footnotetext{
${ }^{8}$ In the above accounting framework, $\Omega^{s}$ (where $\Omega$ stands for offshore, and $s$ for Switzerland) is equal to $\sum_{i \neq s} \sum_{j \neq s}\left(a_{i j}^{s}+\tilde{a}_{i j}^{s}\right)$. Ideally we would like to exclude from the offshore portfolios $\Omega^{s}$ the portfolios of foreign securities that belong to foreign direct reporters $\left(\sum_{i \neq s} \sum_{j \neq s} a_{i j}^{s}\right)$, and we would like to include the portfolios of Swiss securities that belong to foreign households $\left(\sum_{i \neq s} \tilde{a}_{i s}^{s}\right)$. As discussed below, in all likelihood both are relatively small, so that $\Omega^{s}$ is a good proxy for the amount of wealth held in Switzerland that goes completely unrecorded in other countries' positions, $\sum_{i \neq s} \sum_{j} \tilde{a}_{i j}^{s}$.
} 
conduits. ${ }^{9}$ In 2004 there was a survey of the custodial holdings in French banks. In sharp contrast to the Swiss case, almost all the foreign securities in French banks belong to French investors (Gest and Dajean, 2005).

The second interesting result relates to the composition of the offshore portfolios in Swiss banks. Mutual fund shares account for one half, bonds for one-third, and equities for the rest. The SNB does not provide statistics on the type of mutual funds that foreigners own (do they invest in bond funds? equity funds?). But we do know that out of the 8,000 funds registered for distribution in Switzerland, about 4,600 are incorporated in Luxembourg and 1,200 in Ireland. ${ }^{10}$ The data, therefore, reveal a clear pattern, summarized by Figure II. On their Swiss accounts, foreigners do own some U.S. equities, but they mostly own Luxembourg and Irish fund shares (the funds, in turn, invest all around the world).

Investing in a Luxembourg fund through a Swiss account makes perfect sense for a French tax evader: Luxembourg does not withhold taxes on cross-border payments, so the tax evader receives the full dividend paid by the fund on his or her account, and French personal income tax can be evaded, since there is no automatic exchange of information between Swiss banks and the French tax authority. Conversely, a French person has to go through each step of the France-Switzerland-Luxembourg circuit to evade taxes. Investing in a Luxembourg fund through a French bank does not save on taxes. Investing in a Swiss mutual fund through a Swiss bank is also useless, because capital income paid by Swiss corporations is subject to a $35 \%$ advance tax withheld at source by Switzerland. The advance tax can only be refunded when taxpayers self-declare income in their home country. The tax does not apply to income credited to Swiss accounts but paid by foreign corporations, such as Luxembourg funds. This fact explains why the vast majority of the mutual funds distributed in Switzerland are incorporated abroad.

In all likelihood, the foreign securities held in Switzerland by foreigners belong to households. It makes little sense for foreign banks, insurance companies, or investment

\footnotetext{
${ }^{9}$ One common misconception is that having a Swiss account means having Swiss francs or Swiss assets. In general, this is not the case.

${ }^{10}$ See http://www.swissfunddata.ch. Most hedge funds are not registered, hence not covered by these statistics. Section V.A. will specifically address the important case of hedge funds.
} 
funds to entrust their non-Swiss holdings to Swiss custodians: doing so does not secure any tax or regulatory advantage. There is no evidence that Swiss banks provide significant custody services for foreign corporations. There is, by contrast, considerable evidence from newspaper investigations, industry reports, and high-profile tax scandals that they offer extensive wealth management services to foreign individuals. $\Omega^{s}$ is thus a good proxy for household offshore portfolios in Swiss banks. ${ }^{11}$

The foregoing discussion has centered on portfolio wealth. In tax havens, however, households can hold not only securities, but also bank deposits. Swiss banks provide a unique kind of deposit owned by households only, in the form of what are known as fiduciary deposits. Fiduciary deposits cannot be used as a medium of exchange: they are useless for corporations. Swiss banks invest the funds placed in fiduciary deposits in foreign money markets on behalf of their clients. Legally speaking, all interest is considered to be paid by foreigners to the depositors, with the Swiss banks acting merely as "fiduciaries." Thus, fiduciary deposits are not subject to the $35 \%$ Swiss advance tax. As shown by Table II, in 2008 fiduciary deposits accounted for one-quarter of the total amount of offshore wealth in Swiss banks.

\section{III.B. Who Owns Swiss Bank Accounts?}

The last contribution made by the Swiss data is to provide unique evidence as to the likely owners of unrecorded fortunes in tax havens. Since 1976, the SNB has published a full country breakdown of the owners of fiduciary deposits.

Country breakdowns are puzzling at first glance. As Figure III shows, the SNB records a large and growing fraction of Swiss fiduciary deposits as belonging to tax havens, most notably Panama, Liechtenstein, and the British Virgin Islands. What happens? The SNB records such holdings because it does not see through sham corporations used

\footnotetext{
${ }^{11}$ Note that the SNB provides a breakdown of $\Omega^{s}$ by owner sector (private customers, commercial customers, and institutional investors). But this breakdown is misleading: the SNB does not see through intermediate wealth-holding structures used by individuals with a Swiss account. The SNB counts the securities of a French individual who uses a sham Panamanian holding company as belonging to the foreign "institutional investors" sector. This is a first-order issue: few individuals have an account in Switzerland with their own personal address; most Swiss bank clients use intermediate wealth-holding structures (see Section III.B. below).
} 
by households. If a French saver opens an account in the name of a shell company incorporated in Panama, the SNB assigns the funds to Panama. Using sham corporations as nominal owners of Swiss accounts has a long tradition, dating back to at least the end of the Second World War (Schaufelbuehl, 2009). Once you understand the purposes that sham corporations serve, it becomes clear that most fiduciary deposits assigned to tax havens by the SNB belong to residents of rich countries, in particular to Europeans.

A sham corporation adds a layer of secrecy between the owner of a Swiss account and his holdings, making it harder for tax authorities to investigate cases of tax evasion. When tax evaders combine numerous sham corporations in multiple tax havens, foreign authorities have practically no way to find out who is the beneficial owner of a Swiss account. Sham corporations are less useful to residents of countries where there is no income tax or where tax administrations have no resources to investigate offshore tax evasion. Sham corporations also help Europeans evade taxes. The European Union has adopted the Savings Directive in a move to curb tax evasion: since 2005, Swiss and other offshore banks must withhold a tax on interest earned by European Union residents. ${ }^{12}$ But the Directive only applies to accounts opened by European households in their own name; sham corporations are a straightforward way of eschewing it.

Figure III shows that there is a clear negative correlation between the share of fiduciary deposits held by Europeans and the share of fiduciary deposits assigned to tax havens. European depositors have shifted their deposits to sham corporations over time. They reacted particularly strongly to the introduction of the EU Savings Directive in July 2005: between December 2004 and December 2005, Europe's share of Swiss fiduciary deposits declined by 10 percentage points while tax havens gained 8 percentage points. ${ }^{13}$ Zaki (2010, p. 54) documents how Swiss bankers created sham corporations on a large scale during the summer of 2005 to help their European clients circumvent the Directive.

The U.S. Internal Revenue Service (IRS) provides additional evidence that rich countries' residents use sham corporations extensively. In 2009, the IRS released case studies

\footnotetext{
${ }^{12}$ In July 2011, the tax rate was set at 35\%. Tax havens keep one-quarter of the tax revenue and transfer the remaining three-quarters to the European country where the account owner is resident. This withholding tax allows tax havens to avoid automatic exchange of bank information, the EU standard.

${ }^{13}$ See Johannesen (2010) for an analysis of the reaction of Swiss bank deposits to the Directive.
} 
of tax evasion by U.S. residents in a big Swiss bank. ${ }^{14}$ In almost all cases, U.S. tax evaders owned their accounts through sham entities incorporated in Panama, the British Virgin Islands, and Hong Kong. Many of them had transferred their accounts to shell companies in the 1990s or 2000s. In many IRS cases, the sums involved are huge, attaining $\$ 100$ million for a single family in a single bank.

Let's assume that in 2004, before the EU Savings Directive, if a country owned $10 \%$ of the fiduciary deposits not assigned to tax havens, it also owned $10 \%$ of the deposits assigned to tax havens. Let's also assume that Gulf countries do not use sham corporations, which is plausible since they have no capital income tax. Then the rich world owned $62 \%$ of Swiss fiduciary deposits in $2004 .{ }^{15}$ Contrary to popular belief, there is no indication that African dictators or rich Asian investors own the bulk of Swiss accounts.

\section{An Estimate of the Global Offshore Wealth}

Switzerland is not the only tax haven that offers wealth management services to foreign individuals. Just like in Switzerland, banks incorporated in the Bahamas, Singapore, and other havens with strict bank secrecy rules attract foreign individuals and provide them with similar private banking services - securities custody and investment advice. ${ }^{16}$ The goal of this Section is to present a novel method to estimate the amount of wealth held by individuals through all the world's tax havens. The method is independent from the official Swiss statistics, which will enable us to check its results against the Swiss data.

\section{IV.A. Using Anomalies in Countries' Portfolio Securities Data}

The method exploits the anomalies that the personal wealth management activities of tax havens cause in the portfolio data of countries. Take the typical investment revealed

\footnotetext{
${ }^{14}$ http://www.irs.gov/uac/Offshore-Tax-Avoidance-and-IRS-Compliance-Efforts.

${ }^{15}$ See Appendix, Table A26.

${ }^{16}$ The testimony of a former Cayman banker can be read in U.S. Senate (2001). Many of the large global banks have subsidiaries with private wealth management activities in Hong Kong, the Cayman Islands, and so on. Based on interviews with offshore wealth managers, the Boston Consulting Group (2009) estimates that about a third of the global offshore wealth is in Switzerland; 20\% in Jersey, Guernsey, and Ireland; $20 \%$ in the Caribbean and the U.S.; 15\% in Luxembourg; 10\% in Singapore and Hong Kong.
} 
by the Swiss data: French residents who own Luxembourg fund shares through their Swiss accounts. (In turn, the Luxembourg funds invest in U.S. bonds, German equities, and so on, but forget about the investments made by the funds: they are irrelevant for the argument). These fund shares should be recorded as portfolio assets for France and liabilities for Luxembourg. ${ }^{17}$ In practice, France has no way to record assets. Luxembourg statisticians duly record portfolio liabilities - they are aware that foreigners own shares of domestic funds. ${ }^{18}$ And Switzerland rightly records nothing on its balance sheet. Portfolio liabilities are bound to exceed assets globally.

The same argument applies when you replace France by any country $i$ whose households use tax havens (say the U.S.), Switzerland by any tax haven $k$ that hosts personal wealth management activities (say the Bahamas), and Luxembourg by any country $j$ that attracts investments or where a lot of mutual funds are incorporated (say the U.K.). Denote $L_{j}$ the portfolio liabilities of country $j, A_{i j}$ the true assets of country $i$ on country $j$, and $\hat{A}_{i j}$ statisticians' estimates. Because of the personal wealth management activities of tax havens, there will be a fundamental anomaly in the portfolio stock data of countries:

Anomaly 1: More cross-border portfolio liabilities $\sum_{j} L_{j}$ than assets $\sum_{j} \sum_{i} \hat{A}_{i j}$ will be recorded at the global level.

Corollary of Anomaly 1: For the countries $j$ in which holders of offshore accounts invest, debtor-reported portfolio liabilities $L_{j}$ will be greater than creditor-derived liabilities $\sum_{i} \hat{A}_{i j}$.

Tax havens also cause anomalies in flow data. First, statisticians usually compute dividends and interest income by applying representative yields to stock positions, be-

\footnotetext{
${ }^{17}$ In international investment statistics, mutual funds are treated as regular corporations, they are never made transparent. All mutual fund shares are classified as a type of portfolio equities (even the shares issued by mutual funds that only invest in bonds). This statistical convention can be seen as bizarre, but it is uniformly applied across the world. To clarify matters, I keep the word "equity" for regular portfolio equities and distinguish equities from fund shares.

${ }^{18}$ Note that the investments made by Luxembourg funds are also duly recorded: U.S. equities purchased by the funds will be recorded as portfolio assets for Luxembourg and liabilities for the U.S. Further, imagine that the funds in Luxembourg are in fact affiliates of German financial companies. In top of everything else, Luxembourg will record a direct investment liability and Germany an asset. The value of the direct investment will be the residual net worth of the funds (e.g., the value of the funds' offices), which is very small compared to the funds' gross portfolio assets and liabilities. Any error here does not affect the argument.
} 
cause observed positions are considered more reliable than flows. ${ }^{19}$ If some securities are missing from the stocks, then Anomaly 2 follows:

Anomaly 2: More cross-border dividends and interest will be paid than received globally.

In addition, offshore banks do not only provide custody but also brokerage services: they buy and sell securities on behalf of their clients. Take a U.S. individual who purchases U.K. equities from her account in the Bahamas. In principle, Bahamian statisticians will notice that the buyer is not a resident of the Bahamas, so in keeping with the residence principle they will not record any equity purchase. ${ }^{20}$ The U.K., by contrast, will duly record a sale.

Anomaly 3: When offshore account holders are net purchasers of securities, more securities are sold than purchased globally. (And more securities are purchased than sold when offshore account holders are net sellers).

Transfers of funds to tax havens can also cause anomalies. Take a U.S. saver who wires funds to the Bahamas. Following the double-entry bookkeeping system used in balance of payments accounting, such a transfer must be recorded twice in the U.S.: both as an other investment credit (funds flow from a U.S. bank to a Bahamian bank) and an other investment debit (a U.S. person purchases a foreign asset, namely a Bahamian bank deposit). ${ }^{21}$ In practice, a credit will be recorded but a debit will not, thus causing negative net errors and omissions in the U.S. ${ }^{22}$

U.S. savers can also purchase securities from their onshore accounts and then entrust them to offshore banks for custody. In this case, U.S. portfolio investment flow data will be accurate but the positions will not: there will be negative other changes in the statistics that reconcile flows and stocks as per the identity $\Delta$ Stocks $=$ Flows + Valuation + OtherChange.

\footnotetext{
${ }^{19}$ See for instance BEA (2011, p. 42) in the case of the U.S.

${ }^{20} \mathrm{~A}$ practical reason why they will indeed not record a purchase is that transaction data are increasingly inferred from variations in observed positions - and statisticians do establish positions in keeping with the residence principle, as the Swiss data exemplify.

${ }^{21}$ In the financial account of the balance of payments, credits denote a reduction in assets or an increase in liabilities, while debits denote an increase in assets or a reduction in liabilities.

${ }^{22}$ See Appendix D.4.2 for a detailed analysis.
} 
Anomaly 4: In individual countries' statistics, some transfers of funds to tax havens cause net errors and omissions and flow-stock discrepancies.

But tax evaders can also carry banknotes, gold, and diamonds overseas. Such transfers will go fully unrecorded in U.S. international accounts, and thus will not cause any anomalies. Funds legally earned are unlikely to be massively transferred this way but funds illegally earned may well be.

We can use Anomaly 1 to compute the value of the assets globally held unrecorded by households in all the world's havens provided we make two assumptions. On the asset side, we need to assume that the securities held by direct reporters (such as financial corporations and governments) and those held onshore by households are well measured globally (H1). Second, the global amount of recorded portfolio liabilities must be accurate (H2). Under these assumptions, the global gap between identifiable portfolio liabilities and assets captures the value of the portfolios held by households through all tax havens. In this paper, my estimate of the unrecorded wealth in all tax havens is equal to the difference between globally identifiable portfolio liabilities and assets.

At first glance, this estimation method might seem trivial and crude. It is neither. It requires quite a lot of data, some of which have become available only recently and are assembled here for the first time. More importantly, although assumptions (H1) and (H2) are not fully verified in practice, they are reasonable starting points and the results are robust to relaxing them.

Leaving aside household offshore wealth, portfolio positions are indeed considered quite reliable. Securities markets are highly centralized. Most countries have a longstanding tradition of monitoring custodians, and custodians observe all the securities held onshore. There is usually no valuation issue: traded stocks and bonds have readily available market prices. That is why, in a reference article, Bertaut, Griever, and Tryon (2006, p. A67) write that: "In general, the data on U.S. liabilities are considered to be reasonably comprehensive [my assumption H2 in the U.S. case], as debt instruments tend to be issued by and bought or sold through large institutions that can be fairly readily identified and included in the data reporting network. U.S. foreign assets held by or 
through large U.S. institutions should also be well recorded [H1]." ${ }^{23}$

The relatively good quality of portfolio stock data extends to other leading countries. In response to a number of reports (IMF, 1987; 1992), the IMF launched in the 1990s a program to harmonize collection methods and spread best practices across the world (IMF, 2002). Since 2008, in all leading economies portfolio asset data have been based on security-by-security surveys. These surveys collect information at the level of individual securities, allowing for extensive cross-checking and error spotting.

Some issues do remain. But as we will see, they are minor for the paper's results. What they simply mean is that my method to compute the wealth in all the world's havens can only give an order of magnitude - not an exact figure as in the Swiss case.

\section{IV.B. Data on Countries' Aggregate Portfolio Securities}

To compute the value of the global offshore portfolio using Anomaly 1, we need aggregate portfolio securities asset and liability figures for all countries. The key source is the August 2009 updated and extended version of the External Wealth of Nations dataset constructed by Lane and Milesi-Ferretti (2007), which covers 178 economies. In the database, portfolio position data come from published IIPs or in minor cases are derived by cumulating flows and adjusting for valuation effects. ${ }^{24}$

There are three data challenges here: the External Wealth of Nations does not include data for all the world's territories; I want to include the securities held by central banks (which are classified as "reserves") in my portfolio assets total; and there are uncertainties on the holdings of Middle Eastern oil exporters. To address these challenges, many studies exist to rely on, drawing on independent sources. By construction, my figures are in line with these studies, which makes me confident in their accuracy. When uncertainties remain, they can be quantified and they are small compared to my estimate of the global

\footnotetext{
${ }^{23}$ The authors then go on by describing the problem in which we are precisely interested in this paper: "However, for smaller U.S. investors, directly purchasing foreign securities abroad without using the services of a large, U.S.-resident institution is increasingly easy. Such acquisitions will not be captured in the U.S. recording system but will most likely be recorded as liabilities by the counterparty country's measurement system. Because all countries face this problem, cross-border assets are probably undercounted worldwide."

${ }^{24}$ Starting in 2001, the portfolio data for almost all the largest economies and financial centers come from published IIPs. That is why I only use post-2001 data in this research.
} 
offshore wealth.

First, filling in the coverage gaps in the External Wealth of Nations database does not pose major difficulties. The only significant country not covered is the Cayman Islands, a large financial center where about 10,000 hedge funds are incorporated. ${ }^{25}$ But the Cayman Islands' Monetary Authority has been publishing data on the holdings of Cayman hedge funds since 2006. Based on this information, I reckon that the Cayman Islands had about $\$ 1.25 \mathrm{tr}$ in portfolio assets at the end of 2008 , of which about $\$ 700 \mathrm{bn}$ were U.S. equities and bonds. ${ }^{26}$

Second, most countries disclose to the IMF what fractions of their reserves are held in the form of bank deposits versus bonds and other securities. ${ }^{27}$ Notable exceptions include China and Taiwan. On average, central banks invest $75 \%$ of their assets in securities and $25 \%$ in bank deposits; I assume that the same holds true for those countries that do not provide data. However, Wooldridge (2006) suggests that the share of securities is probably higher in China, so I assume a $85 \%$ securities share for China. There is a $\$ 100-$ 200bn uncertainty on China's portfolio and a 30\$bn uncertainty on Taiwan's. ${ }^{28}$ This is negligible compared to my estimate of the global offshore wealth $(\$ 4,500$ bn in 2008$)$.

Lastly, little public information exists about oil exporters' holdings. In principle, one could use counterpart country data - such as the Treasury survey of U.S. portfolio liabilities - to capture oil exporters' assets. But oil exporters sometimes invest abroad through offshore banks; the U.S. securities that they hold through Swiss banks will wrongly be attributed by the U.S. to Switzerland.

To estimate oil exporters' onshore assets, I start with their holdings of U.S. securities as recorded in the Treasury liabilities survey. I then make assumptions regarding the share of U.S. securities in their portfolio. The many studies recently published on the

\footnotetext{
${ }^{25}$ For the other countries not covered, see Appendix Sections B.3 and B.4.

${ }^{26}$ Although there remains some uncertainty on the holdings of Cayman hedge funds, this does not affect my estimate of household offshore wealth, because I use the same method to compute the Cayman Islands' assets as to compute its liabilities. If my assets estimate is $\$ 200 \mathrm{bn}$ too small, then my liabilities estimate is also $\$ 200 \mathrm{bn}$ too small, leaving the global assets-liabilities gap unchanged. See Sections A.2 and B.3.1 of the Appendix for more details on the Cayman Islands.

${ }^{27}$ The two key sources here are the IMF Special Data Dissemination Standard and an IMF survey of securities held as reserve assets, called SEFER.

${ }^{28}$ See Appendix Sections A.4 (China) and A.6.2 (Taiwan and other non-SEFER reporters).
} 
subject share two conclusions: the U.S. share is high and it has declined in the 2000s. The assumption for 2001 of a $70 \%$ share of U.S. assets and a regular decline of two percentage points per year fits the available estimates best. To simplify matters, I do not try to specifically estimate the value of oil exporters' offshore assets; I include these in my globally unrecorded offshore wealth total. Although some uncertainties remain, available studies, official sources, and Swiss statistics suggest that oil exporters account for about $10 \%$ of my estimated total offshore wealth $\Omega .{ }^{29}$

\section{IV.C. The Global Portfolio Assets-Liabilities Gap}

Exploiting the global database, Figure IV reveals a first striking result: each year, less securities assets than liabilities are identifiable worldwide. In 2008, liabilities $\sum_{i} L_{i}$ equal $\$ 40 \operatorname{tr}$, while assets $\sum_{i} \hat{A}_{i}$ reach $\$ 35.5 \operatorname{tr}$ only. There is a $\$ 4.5 \operatorname{tr}$ gap $\Omega=\sum_{i} L_{i}-\sum_{i} \hat{A}_{i}$. (Note that selecting 2008 as the benchmark year tends to understate the absolute size of unrecorded claims given the collapse in world equity prices after the Lehman Brothers bankruptcy). Each year, more than $10 \%$ of all cross-border equities and bonds have unknown owners. Figures V and VI plot the discrepancy for equities (including fund shares) and bonds separately. $20 \%$ of all cross-border equities and fund shares have no identifiable owners; bonds are less affected.

Table III compares the portfolios that have no readily identifiable owners globally $(\Omega)$ with the offshore portfolios in Swiss banks $\left(\Omega^{s}\right)$, as of the end of 2008. Both look strikingly the same, although they rely on fully independent data. In each case, equities including fund shares account for two thirds, bonds for one third. (And as we will see below, most of the globally missing equities are actually mutual fund shares, just like most of the equities held through Swiss offshore accounts). This fact suggests that the global portfolio assets-liabilities gap does reflect the assets held by households through tax havens. One third of the global missing wealth $(\Omega=\$ 4,490 \mathrm{bn})$ can be traced back to Switzerland $\left(\Omega^{s}=\$ 1,545 \mathrm{bn}\right)$, a finding consistent with industry reports estimating that about a third of the world's offshore wealth is in Switzerland (e.g., Boston Consulting

\footnotetext{
${ }^{29}$ Section A.5 of the Appendix provides a thorough discussion of oil exporters.
} 
Group, 2009).

At end 2008, the global net financial wealth of households - households' bank deposits, equities, bonds, and insurance contracts, net of debts - was about $\$ 74 \operatorname{tr}^{30}$ By my estimate, individuals held unrecorded portfolios worth $\Omega=\$ 4.5 \operatorname{tr}$ in tax havens - that is, about $6 \%$ of their net financial wealth.

In tax havens households not only own portfolio securities but also bank deposits. Contrary to what happens for portfolios, offshore deposits do not go completely unrecorded in the international statistics. The major financial centers tell the Bank for International Settlements (BIS) how much deposits foreigners have placed in their banks. In principle, French statisticians can use the BIS data to estimate the value of French residents' offshore bank deposits, which will then be recorded in France's IIP as "other assets." The IMF has been advocating the use of the BIS data by national agencies since the 1990s. Not all countries do so, however, and the BIS does not separate out corporate from household deposits.

In order to give a rough estimate of the global amount of household offshore wealth, I assume in the first column of Table III that $25 \%$ of it takes the form of deposits and $75 \%$ of securities, as is the case in Switzerland. In 2008, global offshore wealth then amounts to $\$ 4.5 \operatorname{tr}$ (securities) plus $\$ 1.4 \operatorname{tr}$ (deposits). The resulting $\$ 5.9 \operatorname{tr}$ total represents $8 \%$ of household financial wealth. Of this $8 \%$, at most $2 \%$ (deposits) are recorded as assets in countries' IIPs. ${ }^{31}$

While this paper is the first in the academic literature to estimate the personal wealth held in tax havens, a number of studies have provided estimates before. The most detailed industry report puts the amount of household offshore wealth at $\$ 6.7 \operatorname{tr}$ in 2008 (Boston Consulting Group, 2009, p. 31). Cap Gemini and Merrill Lynch (2002, p. 11) put it

\footnotetext{
${ }^{30}$ This figure comes from the work of Davies et al. (2011) who provide the first comprehensive estimate of the level and distribution of world wealth in 2000 based on an exhaustive exploitation of available national balance sheets. A report by Credit Suisse (2010) builds on the methodology developed by Davies et al. (2011) to provide yearly estimates for the 2000-2010 period, and finds $\$ 74$ tr for 2008 .

${ }^{31}$ Deposits are only partially recorded, because not all statisticians use the BIS data as inputs to their IIPs. And more importantly, the BIS data under-estimate the offshore deposits of rich countries' households, because they do not see through the intermediate wealth-holding structures that the owners of offshore accounts use. The Swiss bank deposits held by French savers through sham Panamanian corporations are assigned to Panama in the BIS data. This is a first-order concern (see Section III.B).
} 
at $\$ 8.5 \operatorname{tr}$ in 2002. The Tax Justice Network (2005) has a $\$ 11.5 \operatorname{tr}$ figure for 2005 and Palan, Murphy, and Chavagneux (2010, p. 5) write that "the global rich held in 2007 approximately $\$ 12$ trillion of their wealth in tax havens." My estimate, $\$ 5.9 \operatorname{tr}$ in 2008 , is therefore at the low-end of the scale. Note that I focus on financial wealth only, whereas households can also use tax havens for works of art and real estate. ${ }^{32}$

\section{Consistency and Robustness Checks}

My method to estimate the personal wealth globally held offshore is indirect, and as such subject to a margin of error. Future statistical improvements will make it possible to refine my estimate. In the meantime, this Section provides evidence that the order of magnitude I find is correct, robust to relaxing the key estimation assumptions, and consistent with independent flow data.

\section{V.A. Using Bilateral Assets Data to Decompose the Assets-Liabilities Gap}

A basic objection to my estimation procedure is that the global portfolio assets-liabilities gap may reflect data deficiencies unrelated to tax havens. How can we be reasonably sure that it mostly reflects household offshore portfolios? Because of one key reason: the wealth does not vanish randomly, but following a specific pattern that closely mirrors what the independent Swiss data show.

To make this point, I use bilateral portfolio assets data to decompose the global portfolio assets-liabilities gap $\Omega$ and investigate its source. The main data source is the Coordinated Portfolio Investment Survey (CPIS), conducted under the auspices of the IMF on a yearly basis since 2001. I use the 2008 wave of the survey, which presents the bilateral portfolio holdings $\hat{A}_{i j}$ of 74 countries on 238 debtors. The CPIS is rounded out by a survey of securities held as reserve assets and by international organizations.

In its early years, the CPIS had important shortcomings. Initially, only 7 of the

\footnotetext{
${ }^{32}$ Whether these elements can explain the difference between my estimate and previous studies is a question that I leave for future research. Cross-border real estate, in particular, is an important asset class for households. I also disregard the wealth of individuals who live in tax havens.
} 
countries surveyed by the IMF conducted the security-by-security surveys required to accurately measure bilateral portfolio holdings. The majority of the entries in the CPIS were estimated by participating countries on the basis of ad hoc methods. Over the years, progress was made. In 2008, most leading economies conducted security-by-security surveys, including the U.S., the entire eurozone, and Japan. For these countries, the geographical allocation of assets is likely to be very accurate. ${ }^{33}$ Some problems still remain. The U.S., for instance, does not currently count short positions as negative assets, so reported figures are slightly too high. There are some valuation issues: when partial repayment of a debt security is possible, as is the case for asset-backed securities, some custodians keep track of the original principal, others only of what is remaining. But as Section V.B. will show, these shortcomings cannot affect the main conclusions I draw from the analysis of the CPIS data.

To analyze the source of the global gap $\Omega$ we need bilateral portfolio assets data for all countries. I have therefore filled in the coverage gaps in the CPIS. This is not problematic, because the CPIS has a very good coverage rate: it captures $86 \%$ of all crossborder securities in 2008. ${ }^{34}$ All the leading industrial countries and the large financial centers participate - although the Cayman Islands only reports on its banks' portfolio holdings, disregarding its large hedge fund industry. To reach a 98-99\% coverage rate, we only need to add data on four non-reporters: China, Middle Eastern oil exporters, Taiwan, and the Cayman Islands' hedge funds. We have reasonably good information about the investments these non-reporters make: we know that they invest in the U.S. a lot. To allocate some of the non-U.S. investments of CPIS non-reporters, I employ a gravity model of portfolio holdings. ${ }^{35}$ The online Appendix extensively discusses the raw sources and methods used to fill in the gaps in the CPIS.

Figure VII decomposes the 2008 global portfolio assets-liabilities gap $\Omega$ using the extended CPIS data. Each dot is equal to the difference between the portfolio liabilities

\footnotetext{
${ }^{33}$ See for instance Bertaut, Griever, and Tryon (2006, p. A63) in the case of the U.S.

${ }^{34}$ See Appendix Table A1.

${ }^{35}$ As shown by Portes and Rey (2005) and Lane and Milesi-Ferretti (2008), the gravity model fits cross-border portfolio flow and stock data well. Because I apply the gravity model to less than $5 \%$ of global assets, any error introduced by the model has negligible consequences.
} 
reported by a country $j\left(L_{j}\right)$ and the sum of the assets on $j$ identifiable worldwide $\left(\sum_{i} \hat{A}_{i j}\right)$. By construction, the dots sum to $\$ 4,490 \mathrm{bn}$, the global portfolio gap $\Omega$. For $90 \%$ of the world's countries, debtor-reported and creditor-derived liabilities match $\left(L_{j}=\right.$ $\left.\sum_{i} \hat{A}_{i j}\right)$. But for the three financial centers that host large mutual fund industries Luxembourg, the Cayman Islands, and Ireland - there is a huge discrepancy. ${ }^{36}$ For instance, Luxembourg had around $L_{j}=\$ 2$ tr in equity liabilities at end 2008. Yet only $\sum_{i} \hat{A}_{i j}=\$ 1.1 \mathrm{tr}$ in equity assets on Luxembourg were identifiable worldwide: about $\$ 900 \mathrm{bn}$ of Luxembourg mutual fund shares had no known owner. ${ }^{37}$ Overall, claims on funds incorporated in Luxembourg, Ireland, and the Cayman, account for $48 \%$ of the globally missing wealth $\Omega$.

The missing wealth thus follows a clear pattern that mirrors what the Swiss data showed. We learned in Section III that foreigners own a great deal of Luxembourg and Irish fund shares through their Swiss accounts (Figure II). We now observe that many of such fund shares have no identifiable owners globally (Figure VII). Banks all over the world, and not only in Switzerland, sell Luxembourg and Irish fund shares to their customers - simply because a considerable fraction of the world's mutual funds are incorporated in these two countries that do not withhold taxes on cross-border payments. ${ }^{38}$ The specific pattern of anomalies in Figure VII can thus readily be explained by the fact that households own fund shares through unrecorded accounts in Switzerland, Singapore, and the Bahamas. It cannot satisfactorily be explained by other known issues with the data - including with the 2008 CPIS -, nor by my imputations for non-CPIS participating countries. There is admittedly some uncertainty on the holdings of China, oil exporters,

\footnotetext{
${ }^{36}$ These discrepancies have previously been documented by Lane and Milesi-Ferretti (2007) and the ECB (2009) in the case of Luxembourg and Ireland, and suggested by Lane and Milesi-Ferretti (2011) in the case of the Cayman Islands, but my paper is the first to provide a consistent explanation for them. Section D.4.6 of the Appendix discusses the preliminary steps taken by the ECB to address the issue. Statistical agencies cannot do much until all tax havens disclose who owns the offshore portfolios in their banks (see Section VII).

${ }^{37}$ Almost $100 \%$ of the equity liabilities of Luxembourg, Ireland, and the Cayman are fund shares.

${ }^{38}$ One exception is that not many foreign funds are sold on the U.S. territory, because of restrictions put by the Investment Company Act of 1940. Statistics gathered by the European Fund and Asset Management Association (EFAMA) show that Luxembourg and Ireland are the two leaders for the incorporation of mutual funds in Europe. At the global level, Luxembourg comes second to the U.S. But the U.S. withholds taxes on payments made by domestic funds to foreigners, which explains why in tax havens individuals own Luxembourg rather than U.S. fund shares.
} 
and Taiwan, but no indication that these countries massively invest in Luxembourg and Irish funds. ${ }^{39}$

The large amount of missing claims on the Cayman can also be explained by the use of tax havens by individuals, although the mechanism is slightly different. Most of the funds incorporated in the Cayman are hedge and private equity funds. Shares of such funds are usually directly purchased by investors rather than distributed by Swiss and other banks. Because shares of hedge funds are not entrusted to custodian banks, it is hard for U.S. statisticians to measure U.S. claims on Cayman funds. At the end of 2008, the U.S. recorded less than $\$ 100$ bn in equity assets on the Cayman while funds incorporated there had more than $\$ 1$ tr in foreign equity liabilities. ${ }^{40}$ In all likelihood a large amount of U.S. claims went unrecorded. For U.S. savers, directly investing in Cayman hedge funds offers roughly the same potential tax evasion opportunities as holding Luxembourg fund shares through Swiss accounts. When filling tax returns, taxpayers can choose to report income or not, since there is no automatic exchange of information between Cayman funds and the IRS. ${ }^{41}$

Why should we care that a considerable amount of Luxembourg, Irish, and Cayman fund shares have no identifiable owners? Because the funds in turn invest in U.S. equities and other securities. Since we do not know who owns a large fraction of the world's mutual funds, we cannot know who ultimately owns a large fraction of U.S. equities. ${ }^{42}$

The missing claims on France, Japan, and other rich countries in Figure VII can be attributed to the fact that through their offshore accounts savers directly invest in French equities, Japanese bonds, and other securities issued by rich countries. ${ }^{43}$ Again this would

\footnotetext{
${ }^{39}$ It makes little sense for central banks or sovereign funds to invest in mutual funds (except in hedge funds and private equity funds) since they already pay wealth managers to design suitable investment strategies. The largest sovereign wealth fund, Norway's, discloses its portfolio on a security-by-security basis: it has virtually no assets on Luxembourg, Ireland, and the Cayman Islands.

${ }^{40}$ See Department of the Treasury, Federal Reserve Bank of New York, and Board of Governors of the Federal Reserve System (2009, Table 30 p. 68)

${ }^{41}$ A Foreign Account Tax Compliance Act passed in 2010 seeks to strengthen information reporting. For more information on the taxation of hedge fund investors, see Sheppard (2008). I have no data on what fraction of offshore income goes undeclared in tax returns globally. In the U.S., the IRS estimates that personal income tax evasion through offshore accounts and hedge funds might cost up to $\$ 70 \mathrm{bn}$ annually (Gravelle, 2009).

${ }^{42}$ Along these lines, Section C.2. of the Appendix reckons that at least $15 \%$ of U.S. cross-border portfolio equity liabilities have no identifiable ultimate owner.

${ }^{43}$ In principle, these anomalies could also be attributed to problems in the 2008 CPIS and in my impu-
} 
be congruent with the Swiss data, which showed that households directly own equities and bonds in addition to their Irish and Luxembourg fund shares.

\section{V.B. How Known Issues with Available Data Affect My Estimate}

My estimate that about $6 \%$ of household financial wealth is held unrecorded in all the world's tax havens relies on two assumptions. First, portfolio asset figures must accurately reflect the securities held by corporations and governments and those held onshore by households (H1); second, portfolio liabilities must be accurate (H2). Here I briefly review the main known issues with countries' portfolio data and discuss how relaxing the two assumptions affects the results.

On the asset side, asset-backed securities and short positions are sometimes imperfectly recorded - this, however, cannot explain the considerable amount of globally missing mutual fund shares. The assets surveys of a number of economies also have idiosyncratic weaknesses: in the U.S., some hedge and private equity funds have for a long time been unaware of their reporting duties; in Singapore, official statistics have traditionally excluded important semi-official holders of portfolio claims. ${ }^{44}$ Yet it is unlikely that these shortcomings play an important role for the 2008 pattern of anomalies identified in Figure VII. Between 2009 et 2011, both the U.S. and Singapore significantly strengthened their assets data, ${ }^{45}$ but this did not affect much the pattern of debtor-reported/creditorderived anomalies. In 2011 , for instance, Luxembourg reported close to $\$ 2.6 \mathrm{tr}$ in portfolio equity liabilities, and this was still considerably larger than the $\$ 1.4 \operatorname{tr}$ of equity claims on Luxembourg reported in the CPIS; similarly, Ireland had close to $\$ 1.5 \operatorname{tr}$ in equity liabilities and yet CPIS creditors only $\$ 0.5 \operatorname{tr}$ in assets. ${ }^{46}$ And despite notable statistical

tations. However, there is no particular reason why these problems should specifically cause anomalies for France, Japan, Netherlands, and the U.S., as in Figure VII. Note that France is also one of the leading mutual fund centers in Europe along with Luxembourg and Ireland, and that many multinational corporations are headquartered in the Netherlands.

${ }^{44}$ See Appendix Section A.1.2. In Europe, Germany and Italy traditionally measured portfolio positions by cumulating flows and adjusting for valuation, but security-by-security surveys were introduced respectively in 2006 and 2008. See Appendix Sections A.1.1 (Germany) and B.2.3 (Italy).

${ }^{45}$ At the end of 2011, in the frame of the introduction of a new reporting form, the TIC SLT, the Federal Reserve Board significantly expanded its coverage of U.S. hedge and private equity funds (see Section VI.B below). Singapore integrated semi-official investors in its IIP and CPIS data.

${ }^{46}$ Note that here I do not attempt to estimate the holdings of non-CPIS reporters, including those of Cayman-based hedge funds. 
improvements in the U.S., identifiable equity claims on the Cayman remained smaller than the size of the Cayman fund industry.

A second potential issue has to do with liability figures, which might be overestimated. Take a French person who owns French equities via a Swiss bank. From the viewpoint of international statistics, these equities are not cross-border claims, but they will likely be recorded by French statisticians as liabilities for France. In this case, the use of offshore banks by households does not bias asset data downwards but liability data upwards. However, such round-tripping does not affect the paper's argument. Too much liabilities are recorded globally, and the observed assets-liabilities gap still directly reflects household offshore portfolios.

Liability figures, on the contrary, may be under-estimated. Take a French saver who owns U.S. equities via a Swiss bank. U.S. statisticians will not always be able to record these equities as U.S. liabilities. But these equities will not be recorded on the asset side of the French IIP either. So accounting for them would both deteriorate the U.S.'s net foreign asset position and improve France's by the same amount. The wealth held in tax havens would be even greater than I have found.

In sum, available aggregate portfolio data do not always verify my two identification assumptions. In light of what we know today, however, nothing indicates that my methodology substantially over- or under-estimates the wealth offshore. While future improvements in portfolio statistics will make it possible to refine my estimate, there is no particular reason to expect they could radically affect the order of magnitude I find.

\section{V.C. Consistency Between Flow and Stock Anomalies}

A last consistency check comes from the flow data. The global assets-liabilities gap $\Omega$ has its counterpart in the world balance of payments computed by the IMF independently from the present study. The IMF world balance of payments includes all countries' reports plus undisclosed IMF estimates for all non-reporters. It displays two inconsistencies. First, more investment income is paid than received each year (Anomaly 2). In 2008, 
the discrepancy amounted to $D=\$ 156 \mathrm{bn} .{ }^{47}$ To see how this flow anomaly fits in with my estimated stock anomaly, denote $r_{\Omega}$ the yield on the missing portfolios $\Omega$ - that is, the flow of missing dividends and interest divided by the stock of missing securities. A missing flow of $\$ 156 \mathrm{bn}$ implies a yield of $r_{\Omega}=3.5 \%$, consistent with the average yield on recorded cross-border securities. ${ }^{48}$

Second, barring one exception in 1998, there are more securities sold than purchased globally (Anomaly 3). Again, this anomaly fits in well with the portfolio assets-liabilities gap $\Omega$. To see why, denote $I_{t}$ the net unrecorded purchases of securities, and $V A L_{t}$ the net capital gains on existing unrecorded portfolios. We can write the change in the stock of unrecorded portfolios $\Omega$ between $t-1$ and $t$ as $\Omega_{t}-\Omega_{t-1}=I_{t}+V A L_{t}$. Table IV breaks $\Omega$ down as per this equation. A reasonable pattern emerges: steady inflows, negative valuation effects during equity bear markets, positive valuation effects during bull markets, and reasonable yields $r_{\Omega}$ throughout the period.

One anomaly that is not systematic in the data is "net errors and omissions" in individual countries' balances of payments (Anomaly 4). Over the 1970-2004 period, some countries have exhibited large net errors, such as Italy, Norway, or Russia (Lane and Milesi-Ferretti, 2007, Table 3 p. 243). But some EU countries and the U.S. have not. Does that invalidate my results? Not at all, for two reasons. First, transfers of funds offshore need not systematically cause net errors - carrying banknotes overseas, granting a loan to a shell offshore company, and receiving wage on an offshore account will not. ${ }^{49}$ And conversely, "net errors" reflect many issues unrelated to tax havens such as differences in the timing of trade and financial transactions - that make them a poor indicator of the magnitude of capital flight.

\footnotetext{
${ }^{47}$ See Appendix Table A21.

${ }^{48}$ See Appendix Table A22.

${ }^{49}$ Section D. 4 of the Appendix discusses five concrete case studies of transfers and how they should be recorded.
} 


\section{Implications of Tax Havens for International Imbalances}

In 2008, globally identifiable portfolio liabilities exceeded assets by about $\$ 4.5$ tr. The missing assets must belong to some countries. This Section proposes scenarios as to how accounting for them affects international imbalances - both stock and flow imbalances, commonly referred to as "global imbalances." The scenarios are thought experiments such as: "What is the true U.S. net foreign asset position if the U.S. owns $20 \%$ of the unrecorded wealth?"; as such, they are speculative. However, a number of qualitative findings emerge.

\section{VI.A. The Eurozone and the Rich World are Probably Net Creditors}

As we have seen, about one-third of the missing assets can readily be attributed to households with Swiss accounts, and the remaining two-thirds probably belong to households with accounts in other tax havens. The SNB's statistics suggest that more than half the offshore wealth in Switzerland belongs to Europeans. Although we do not know who owns the offshore wealth in the Cayman Islands and Singapore, surveys of wealth managers give some direction. For instance, the Boston Consulting Group (2009) estimates that $42 \%$ of all offshore wealth belongs to Europeans and $60 \%$ to residents of rich countries.

Table V presents scenarios as to how unrecorded assets affect the net position of the eurozone, officially the world's second largest net debtor. Accounting for the offshore wealth in Switzerland alone considerably improves the eurozone's position. If in addition the eurozone owns $25 \%$ of the offshore portfolios in the world's other tax havens, then it is balanced. If it owns $50 \%$ of all the unrecorded portfolios, it is in actual facts a sizeable net creditor. In all plausible scenarios, the eurozone shifts into the black.

Table VI presents similar computations for the U.S. Accounting for unrecorded assets improves the U.S. net position, albeit by a smaller amount. If U.S. residents own $20 \%$ of all unrecorded wealth - say, $15 \%$ of the offshore wealth in Swiss banks and $25 \%$ of the other missing assets - then the net position of the U.S. is significantly better than in the official data: $-12 \%$ of GDP on average over $2001-2008$ as opposed to $-18 \%$ in the data. 
My benchmark scenario where the eurozone owns about half the unrecorded wealth and the U.S. $20 \%$ turns the overall rich world into a net creditor. This result is robust to alternative assumptions. The rich world shifts into the black as long as it owns more than half the globally unrecorded assets. Available Swiss data suggest that it is a lower bound, which is hardly surprising since residents of rich countries own $80 \%$ of recorded world wealth (Davies et al., 2011). Remember also that most of the unrecorded assets are Luxembourg, Irish, and Cayman fund shares. We have reason to believe that these fund shares belong in the main to Europeans (especially Luxembourg fund shares) and Americans (especially Cayman fund shares). ${ }^{50}$ Developing countries have offshore accounts too, but plausibly not more than $30 \%$ of all offshore wealth: about $10 \%$ for oil exporters and $20 \%$ for non-oil developing countries is a reasonable take in light of available evidence. ${ }^{51}$ Lastly, among rich countries, Japanese residents do not seem to use tax havens extensively - they own less than $1 \%$ of Swiss bank deposits - plausibly because capital income is much less taxed in Japan than in other developed economies. ${ }^{52}$

\section{VI.B. Implications for Current Account Dynamics}

Accounting for tax havens sheds light on the true size of debtor and creditor positions: the eurozone is likely to be a net creditor and the U.S. less indebted than in the official statistics. Although my methodology focuses on positions rather than transactions, the results have two implications for the analysis of current accounts dynamics.

First, we know that capturing household offshore portfolios has always been impossible. Although available data do not enable me to estimate the wealth held unrecorded before 2001, accounting for the missing assets must improve the pre-2001 net positions

\footnotetext{
${ }^{50}$ Felettigh and Monti (2008) document that about half the foreign equity holdings recorded by Italy are in Luxembourg funds. The ECB (2009) considers that most of the missing assets on Luxembourg and Ireland probably belong to eurozone residents. Lane and Milesi-Ferretti (2007) document that Irish statisticians recorded five times more U.S. investments in Irish equities than U.S. statisticians did in 2004, so U.S. residents may own a significant fraction of the missing claims on Ireland.

${ }^{51}$ The hypothesis that Middle Eastern oil exporters own $10 \%$ of the globally unrecorded portfolios $\Omega$ implies total portfolio holdings for Middle Eastern countries well in line with the literature, see Appendix Table A8. Middle Eastern countries own $10 \%$ of Swiss bank deposits and non-oil developing countries 25\%, see Appendix Table A26.

${ }^{52}$ In 2005, the OECD reports that the net personal tax rate on dividends was $22 \%$ in Germany, $32 \%$ in France, as opposed to $10 \%$ in Japan, and $18 \%$ in the United States.
} 
of Europe and the U.S. The rich world was therefore probably a sizeable net creditor in the 1980s and 1990s (Figure I). Now, if the rich world starts from a positive position in the mid-1990s, then poor-to-rich flows are a factor of convergence rather than divergence in the external positions of countries: developing countries are simply repaying their debts to advanced economies, as if output convergence was accompanied by net external wealth convergence. Although this is not necessarily what theory predicts - many open-economy models do not have clear-cut predictions on steady-state net foreign asset positions, and in standard models one can have persistent inequalities in net wealth even if output converges -, it seems important to keep this possibility in mind when analyzing the determinants of current account imbalances and the risks involved.

A second implication of my findings is that some of the most egregious inconsistencies between financial flow and stock data, both in Europe and the U.S., may be related to tax havens.

Consider households moving portfolio securities to offshore accounts. The securities leave the radar of domestic statistical systems. This tends to make recorded portfolio positions smaller than cumulated past financial flows adjusted for valuation changes. Such capital flight probably explains in part why the eurozone's net international position has deteriorated from about zero in 1985 to -14\% of GDP in 2011, despite zero current account deficit. A case in point is the dramatic evolution of Ireland's net international position during the crisis, from about $-20 \%$ of GDP in 2007 to $-100 \%$ in 2010 . This development cannot satisfactorily be explained by financial flows and valuation losses (Lane, 2011). Capital flight in the midst of the eurozone crisis has probably played a significant role.

Conversely, statisticians sometimes improve their coverage of the wealth held in tax havens. The U.S., in particular, keeps discovering new portfolio assets from year to year (Curcuru, Dvorak, and Warnock, 2008; Lane and Milesi-Ferretti, 2009). These discoveries partly reflect an improvement in the coverage of U.S. corporations' offshore assets. One prominent example is the 2011 U.S. portfolio asset survey which significantly improved the coverage of the Cayman hedge fund shares held by U.S. companies: the 2011 survey found close to $\$ 500$ bn in Cayman equity assets, three times the 2010 level. Such improvements 
partly explain why the deterioration of the U.S. position has been much smaller than U.S. borrowing and valuation effects would suggest, a puzzle that has attracted considerable attention since the work of Gourinchas and Rey (2007b). The results of the 2011 U.S. survey may be pointing to a gradual reduction in the total amount of unrecorded wealth, as it identified some $\$ 500$ bn in previously unreported holdings. ${ }^{53}$ But a lot of wealth clearly remains to be discovered globally: the U.S. still does not attempt to capture households' offshore portfolios, and in other countries such as Ireland, new waves of capital flight seem to vastly exceed discoveries of previously unreported assets.

\section{VI.C. Remaining Anomalies in International Statistics}

The failure to record the personal wealth in tax havens is certainly not the only issue in the investment statistics of countries. Could other errors in the data offset the improvement in rich countries' IIP resulting from accounting for households' offshore wealth? There is one necessary (though not sufficient) condition for countries' IIP to be accurate: globally, recorded claims should match liabilities. Here I briefly discuss scenarios where this condition is verified.

Accounting for tax havens can entirely solve the global assets-liabilities discrepancy for one category of claims: portfolio investments. It can also explain why more investment income is paid than received, which is the key driver of the current account deficit that the world has tended to run up (Motala, 1997). Two anomalies remain, however. First, contrary to the phenomenon found for portfolio securities, for foreign direct investments, slightly more assets can be identified than liabilities (Lane and Milesi-Ferretti, 2007, Figure 2 p. 232). Second, in a spectacular reversal of past trends, the world started running up a current account surplus in 2004. The surplus has been driven by the trade balance: since 2004, recorded exports have exceeded imports significantly (Figure VIII). Although there is no reason why the FDI and trade anomalies should be linked with household offshore assets, a brief discussion of their likely sources is in order.

FDI data raise huge challenges. Direct investments are decentralized, unlike portfolio

\footnotetext{
${ }^{53}$ See Department of the Treasury, Federal Reserve Bank of New York, and Board of Governors of the Federal Reserve System (2012, Table 4 p. 7).
} 
holdings. Statisticians have only recently started spreading best practices and harmonizing data across countries by means of a Coordinated Direct Investment Survey conducted for the first time in 2009. Most importantly, direct investments have no observable market value, because they do not usually take the form of traded securities. Developing countries compile FDI statistics on a book value basis, while most rich countries try to infer market values based on the market prices of portfolio investments. Because asset prices rose more in developing than in rich countries in the $2000 \mathrm{~s}$, much of the direct investment discrepancy may come from the fact that the book values recorded by the developing countries for their direct investment liabilities are too low. The developing world may be more indebted than we think.

The trade discrepancy also likely comes from errors in developing countries' statistics. There is no particular reason to believe that exports are overestimated in rich countries. In fact, the U.S. Census Bureau (1998) has argued that U.S. goods exports have tended to be systematically underestimated, by as much as $10 \%$. In contrast, there is substantial evidence that the developing world underestimates its imports: Fisman and Wei (2004) show that China's imports from Hong Kong are systematically under-reported for tax reasons. Now, developing countries' IIPs are still mostly compiled by cumulating current account flows (in particular for the "other assets" category). If developing countries' current account balances are overestimated, then their net foreign assets are also overestimated. Once again, the developing world may be more indebted than we think.

If the FDI and trade discrepancies are due purely to errors in developing countries' statistics, then they do not affect the results of this paper: when the world IIP is purged of all its errors, the rich world and the eurozone are net creditors, and the developing world a net debtor. If each country contributes to the FDI and trade discrepancies in proportion to the size of its international balance sheet - a worst case scenario given the available evidence - the central conclusions of this paper still hold. The eurozone remains a net creditor - albeit smaller - and the rich world is roughly balanced. ${ }^{54}$

As a final word of caution, it is worth remembering that in top of the FDI and trade

\footnotetext{
${ }^{54}$ See Appendix Tables A31-A32. Appendix Table A30 provides a line-by-line reconciliation of $\Omega$ with the world net foreign asset discrepancy (the world's puzzling net debt).
} 
issues, there are substantial uncertainties on cross-border holdings of real estate, which in many countries are insufficiently captured or even not at all. Curcuru, Thomas, and Warnock (2009) estimate that on net real estate increased U.S. liabilities of $\$ 565 \mathrm{bn}$ in 2007. Emerging economies might own a substantial fraction of foreign-owned U.S. and European real estate and miss these holdings in their statistics. Further studies are called for on this important issue to improve estimates of the debtor and creditor positions of leading economies.

\section{Conclusion: Two Proposals to Improve Official Statistics}

This paper takes a serious look at the enormous challenges that the personal wealth management activities of tax havens pose for international data. The main finding is that around $8 \%$ of the global financial wealth of households is held in tax havens, threequarters of which goes unrecorded. Available evidence suggests that offshore assets belong in the main to residents of rich countries, in particular to Europeans. On the basis of plausible assumptions, accounting for the wealth in tax havens turns the eurozone into a net international creditor and significantly improves the U.S. net position. Contrary to conventional wisdom that views Europe and the U.S. as severely indebted economies, the rich world is still overall likely to be a net creditor. Much of the literature on global imbalances has been preoccupied with major divergence trends in current accounts and net positions that could ultimately cause a sharp drop in the dollar and recessions in rich countries. My results suggest that poor-to-rich capital flows may be a factor of convergence rather than divergence in the net foreign asset positions of countries.

Accurate foreign asset data are crucial to many research and policy issues. They form a key input for the analysis of patterns in capital flows. Countries with high recorded net foreign debt are labelled high risk, which has direct consequences on their borrowing terms and increases the chances of disorderedly adjustments. Better investment data would improve our ability to track fundamental aspects of globalization and to monitor financial stability. All of this calls for changes to be made to the way data are compiled. 
Two simple reforms would make for substantial improvements. First, statistics showing that $60 \%$ of Swiss deposits are owned by a small set of unpopulated tax havens are unhelpful. Cross-border banking data on the household sector should be compiled on a beneficial ownership basis. A bank deposit owned in Switzerland by a French individual through a sham Panamanian corporation should not be recorded as a Panamanian but as a French deposit. The key principle of anti-money laundering regulations is that bankers need to know at all times who are the beneficial owners of the funds they manage, even if they are held via a long chain of intermediate entities. Banks should be asked to use this information to compile cross-border banking data on the household sector. It would not require much extra work, since the information already exists within the banks.

Second, countries should exchange data on portfolio securities held offshore by households. All international financial centers should report to the Bank for International Settlements on the value of the securities held in custody by foreign residents in their banks - just as they do today for bank deposits. Custodial surveys have a long history and they do not raise any great practical problems. The reform would not violate any bank secrecy provisions. But it would only work if custodial holding data were also established on a beneficial ownership basis.

The combination of both reforms would enable statisticians to fill in long-standing gaps in portfolio investment data. As this paper has argued, this would radically change the international investment positions of rich countries.

A third source can be used as input to the statistics on the external positions of countries: tax data. These data would be reliable if offshore financial institutions exchanged information with foreign tax authorities on an automatic basis. Since the beginning of the financial crisis, and under G20 pressure, a number of tax havens have started exchanging bank information with foreign countries. But they only provide information "upon request:" in practice, the amount of information exchanged remains negligible (Johannesen and Zucman, 2013). Absent automatic information exchange, tax data may well remain an unreliable source to capture the offshore wealth of households. 


\section{References}

M. Aguiar and M. Amador. Growth in the shadow of expropriation. Quarterly Journal of Economics, 126:651-697, 2011.

L. Alfaro, S. Kalemli-Ozcan, and V. Volosovych. Sovereigns, upstream capital flows and global imbalances. NBER Working Paper 17396, August 2011.

A. Atkinson, T. Piketty, and E. Saez. Top incomes in the long run of History. Journal of Economic Literature, 49(1):3-71, 2011.

BEA. U.S. International Transactions Accounts. Bureau of Economic Analysis, Washington, D.C., June 2011.

B. Bernanke. The global saving glut and the U.S. current account deficit. Sandridge Lecture, Virginia Association of Economics, March 2005.

C. C. Bertaut, W. L. Griever, and R. W. Tryon. Understanding U.S. cross-border securities data. Federal Reserve Bulletin, pages A59-A75, 2006.

O. Blanchard and G. M. Milesi-Ferretti. Global imbalances: In midstream? IMF Staff Position Note, December 2009.

O. Blanchard, F. Giavazzi, and F. Sa. International investors, the U.S. current account, and the Dollar. Brookings Papers on Economic Activity, 1:1-49, 2005.

Boston Consulting Group. Global wealth report, "Delivering on the client promise", September 2009.

R. J. Caballero, E. Farhi, and P.-O. Gourinchas. An equilibrium model of "global imbalances" and low interest rates. American Economic Review, 98(1):358-393, 2008.

Cap Gemini and Merrill Lynch. World wealth report, 2002.

C. D. Carroll and O. Jeanne. A tractable model of precautionary reserves, net foreign assets, or sovereign wealth funds. NBER Working Paper 15228, August 2009.

R. H. Clarida, editor. Gry Current Account Imbalances: Sustainability and Adjustment. University of Chicago Press, May 2007.

Credit Suisse. Global wealth report, October 2010.

S. E. Curcuru, T. Dvorak, and F. E. Warnock. Cross-border returns differentials. Quarterly Journal of Economics, 123(4):1495-1530, November 2008.

S. E. Curcuru, C. P. Thomas, and F. E. Warnock. Current account sustainability and relative reliability. In J. Frankel and C. Pissarides, editors, NBER International Seminars on Macroeconomics 2008. University of Chicago Press, 2009.

J. B. Davies, S. Sandström, A. Shorrocks, and E. N. Wolff. The level and distribution of global household wealth. Economic Journal, 121(551):223-254, March 2011. 
F. Dell, T. Piketty, and E. Saez. Income and wealth concentration in Switzerland over the 20th century. In A. Atkinson and T. Piketty, editors, Top income over the twentieth century: A contrast between continental european and english-speaking countires, pages 472-500. Oxford University Press, 2007.

Department of the Treasury, Federal Reserve Bank of New York, and Board of Governors of the Federal Reserve System. Report on U.S. portfolio holdings of foreign securities as of December 31, 2008, October 2009.

Department of the Treasury, Federal Reserve Bank of New York, and Board of Governors of the Federal Reserve System. Report on U.S. portfolio holdings of foreign securities as of December 31, 2011, October 2012.

D. Dollar and A. Kraay. Neither a borrower nor a lender: Does China's zero net foreign asset position make economic sense? Journal of Monetary Economics, 53:943-971, 2006.

M. P. Dooley, D. Folkerts-Landau, and P. Garber. An essay on the revived Bretton Woods system. NBER Working Paper 9971, September 2003.

ECB. Task force on portfolio investment collection systems, final report. Technical report, European Central Bank, June 2002.

ECB. Methodoligcal changes in the compilation of the euro area balance of payments and international investment position. Technical report, European Central Bank, 2009.

C. Engel and J. H. Rogers. The U.S. current account deficit and the expected share of world output. Journal of Monetary Economics, 53:1063-1093, 2006.

A. Felettigh and P. Monti. How to interpret the CPIS data on the distribution of foreign portfolio assets in the presence of sizeable cross-border positions in mutual funds. Evidence for Italy and the main euro-area countries. Banca d'Italia Occasional Paper, August 2008.

R. Fisman and S.-J. Wei. Tax rates and tax evasion: Evidence from "missing imports" in China. Journal of Political Economy, 112(2):471-496, 2004.

I. Gest and A. Dajean. Les placements en valeurs mobilières des agents économiques au quatrième trimestre 2004. Bulletin de la Banque de France, 136, Avril 2005.

P.-O. Gourinchas and H. Rey. International financial adjustment. Journal of Political Economy, 115(4):665-703, 2007a.

P.-O. Gourinchas and H. Rey. From world banker to world venture capitalist: US external adjustment and the exorbitant privilege. In R. Clarida, editor, Gr7 Current Account Imbalances: Sustainability and Adjustment. University of Chicago Press, 2007b.

J. G. Gravelle. Tax havens: International tax avoidance and evasion. National Tax Journal, 62(4):727-753, December 2009.

R. Hausmann and F. Sturzenegger. Global imbalances or bad accounting? The missing dark matter in the wealth of nations and its implications for global imbalances. Economic Policy, 22:469-518, July 2007. 
IMF. Report on the world current account discrepancy. Technical report, International Monetary Fund, Washington, D.C., September 1987.

IMF. Report on the measurement of international capital flows. Technical report, International Monetary Fund, Washington, D.C., June 1992.

IMF. Balance of Payments Manual, 5th edition. International Monetary Fund, Washington, D.C., 1993.

IMF. Offshore financial centers. IMF background paper, International Monetary Fund, Washington, D.C., June 2000.

IMF. Coordinated Portfolio Investment Survey Guide. International Monetary Fund, Washington, D.C., 2nd edition, 2002.

N. Johannesen. Tax evasion and Swiss bank deposits. EPRU Working Paper, May 2010.

N. Johannesen and G. Zucman. The end of bank secrecy? An evaluation of the G20 tax haven crackdown. American Economic Journal: Economic Policy, forthcoming, 2013.

P. R. Lane. The dynamics of Ireland's net external position. Journal of the Statistical and Social Inquiry Society of Ireland, forthcoming, 2011.

P. R. Lane and G. M. Milesi-Ferretti. The externel wealth of nations mark II: Revised and extended estimates of foreign assets and liabilities, 1970-2004. Journal of International Economics, 73(2):223-250, 2007.

P. R. Lane and G. M. Milesi-Ferretti. International investment patterns. Review of Economics and Statistics, 90(3):538-549, August 2008.

P. R. Lane and G. M. Milesi-Ferretti. Where did all the borrowing go? A forensic analysis of the U.S. external position. Journal of the Japanase and International Economies, 23(2):177-199, 2009.

P. R. Lane and G. M. Milesi-Ferretti. Cross-border investment in small international financial centers. International Finance, 14(2):301-330, 2011.

G. Ma and Z. Haiwen. China's evolving external wealth and rising creditor position. BIS Working Paper 286, July 2009.

E. G. Mendoza, J.-V. Rios-Rull, and V. Quadrini. Financial integration, financial deepness and global imbalances. Journal of Political Economy, 117(3):371-410, 2009.

G. M. Milesi-Ferretti, F. Strobbe, and N. Tamirisa. Bilateral financial linkages and global imbalances: A view on the eve of the financial crisis. IMF Working Paper, 2010.

J. Motala. Statistical discrepancies in the world current account. Finance and Development, 34(1):24-25, March 1997.

M. Obstfeld and K. Rogoff. Global current account imbalances and exchange rate adjustments. Brookings Papers on Economic Activity, 1:67-123, 2005. 
M. Obstfeld, J. C. Shambaugh, and A. M. Taylor. Financial stability, the trilemma and international reserves. American Economic Journal: Macroeconomics, 2(2):57-94, 2010 .

R. Palan, R. Murphy, and C. Chavagneux. Tax Havens: How Globalization Really Works. Cornell Studies in Money. Cornell University Press, 2010.

R. Portes and H. Rey. The determinants of cross-border equity flows. Journal of International Economics, 65:269-296, 2005.

J. Roine and D. Waldenström. Wealth concentration over the path of development: Sweden, 1873-2005. Scandinavian Journal of Economics, 111(1):151-187, October 2009.

J. M. Schaufelbuehl. La France et la Suisse ou la force du petit. Evasion fiscale, relations commerciales et financières (1940-1954). Presses de Sciences Po, Paris, 2009.

L. A. Sheppard. Offshore explorations: Caribbean hedge funds, part 1. Tax Notes, page 95, January 72008.

Z. Song, K. Storesletten, and F. Zilibotti. Growing like China. American Economic Review, 101(1):196-233, 2011.

Tax Justice Network. The price of offshore, 2005.

U.S. Census Bureau. Understatement of export merchandise trade data, available online at http://www.census.gov/foreign-trade/misc/expunder.html, 1998.

U.S. Senate. Role of U.S. correspondent banking in international money laundering. Hearings, Permanent Subcommitee on Investigations of the Committee on Governmental Affairs, March 2001.

P. D. Wooldridge. The changing composition of official reserves. BIS Quarterly Review, pages 25-38, September 2006.

M. Zaki. Le secret bancaire est mort, vive l'évasion fiscale! Favre, Lausanne, 2010. 
Figure I: Recorded Net Assets of the Rich World and Estimated Unrecorded Assets Held in Tax Havens

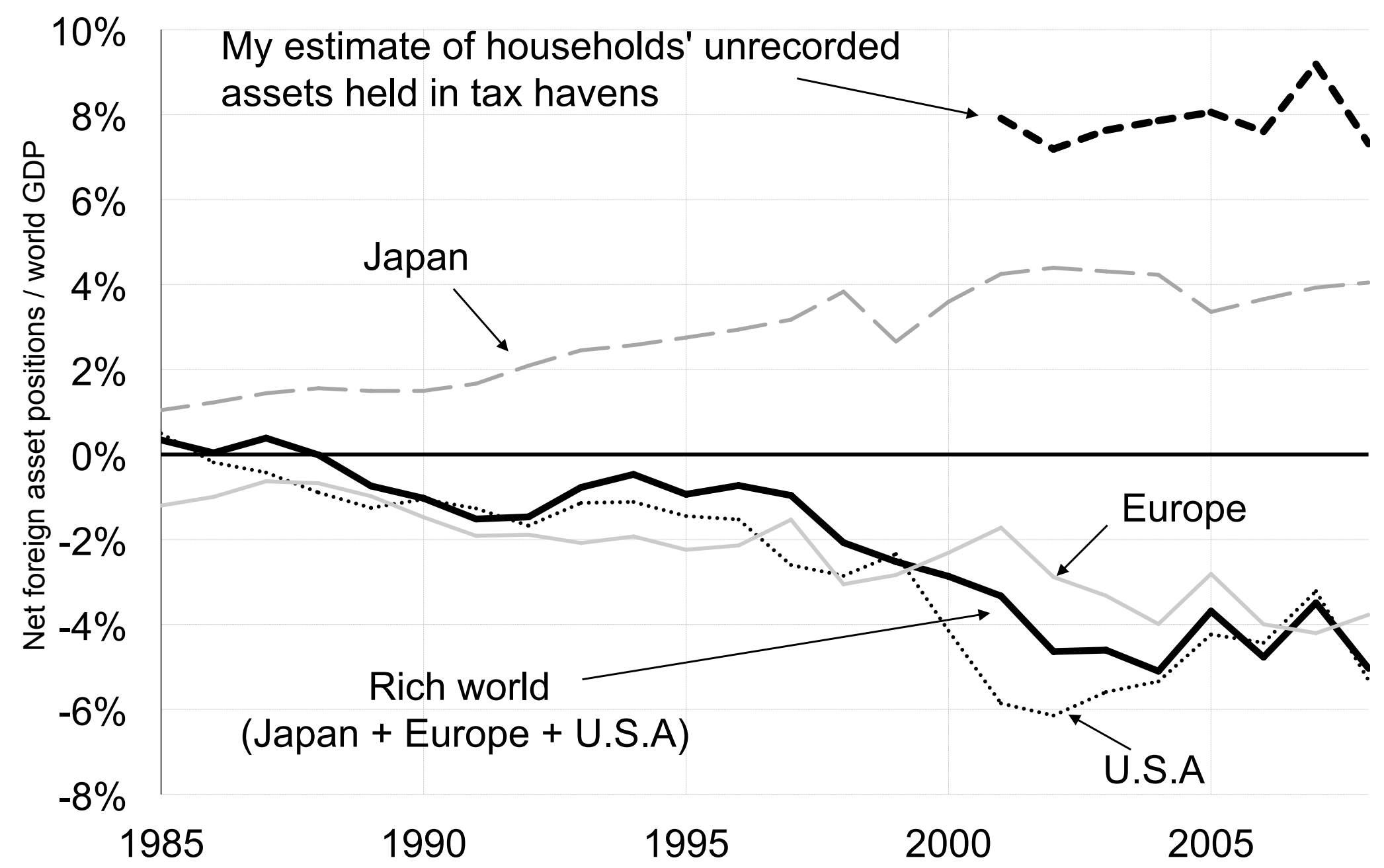

Note: The figure charts the value of unrecorded household assets in tax havens along with the officially recorded net foreign asset positions of Japan, the U.S., and Europe. All series are scaled by world GDP. In 2008, by my estimate, unrecorded household assets amounted to $7.3 \%$ of world GDP. Total household financial assets stood at $120 \%$ of world GDP (Davies et al., 2011) so unrecorded household assets amounted to $6 \%$ of total household financial assets. Europe includes the 16 members of the eurozone as at the end of 2010, five additional European countries (the UK, Norway, Sweden, Denmark and Switzerland), and three non-European countries (Australia, New Zealand, and Canada).

Source: Appendix Tables A3 and A27. 


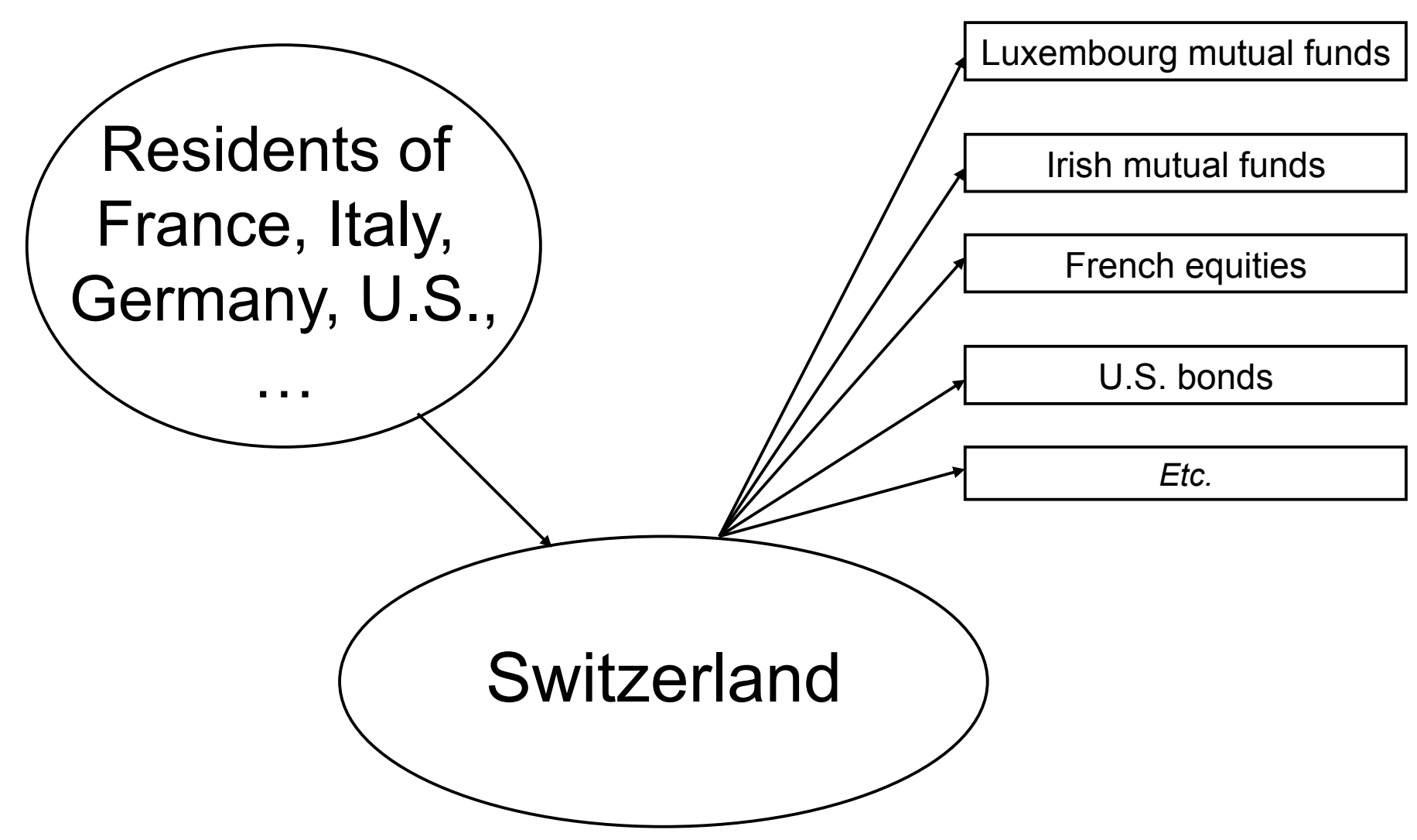

Note: This Figure presents the typical pattern of investments revealed by the Swiss National Bank's statistics studied in this paper. These statistics show that at the end of 2008, foreigners owned about US\$2tr in Swiss banks in the form of bank deposits and portfolio investments. A large fraction of these assets were invested in mutual funds. Most of the mutual funds sold by Swiss banks to their clients are incorporated in Luxembourg and Ireland. 
Figure III: Most Swiss Accounts Probably Belong to Europeans

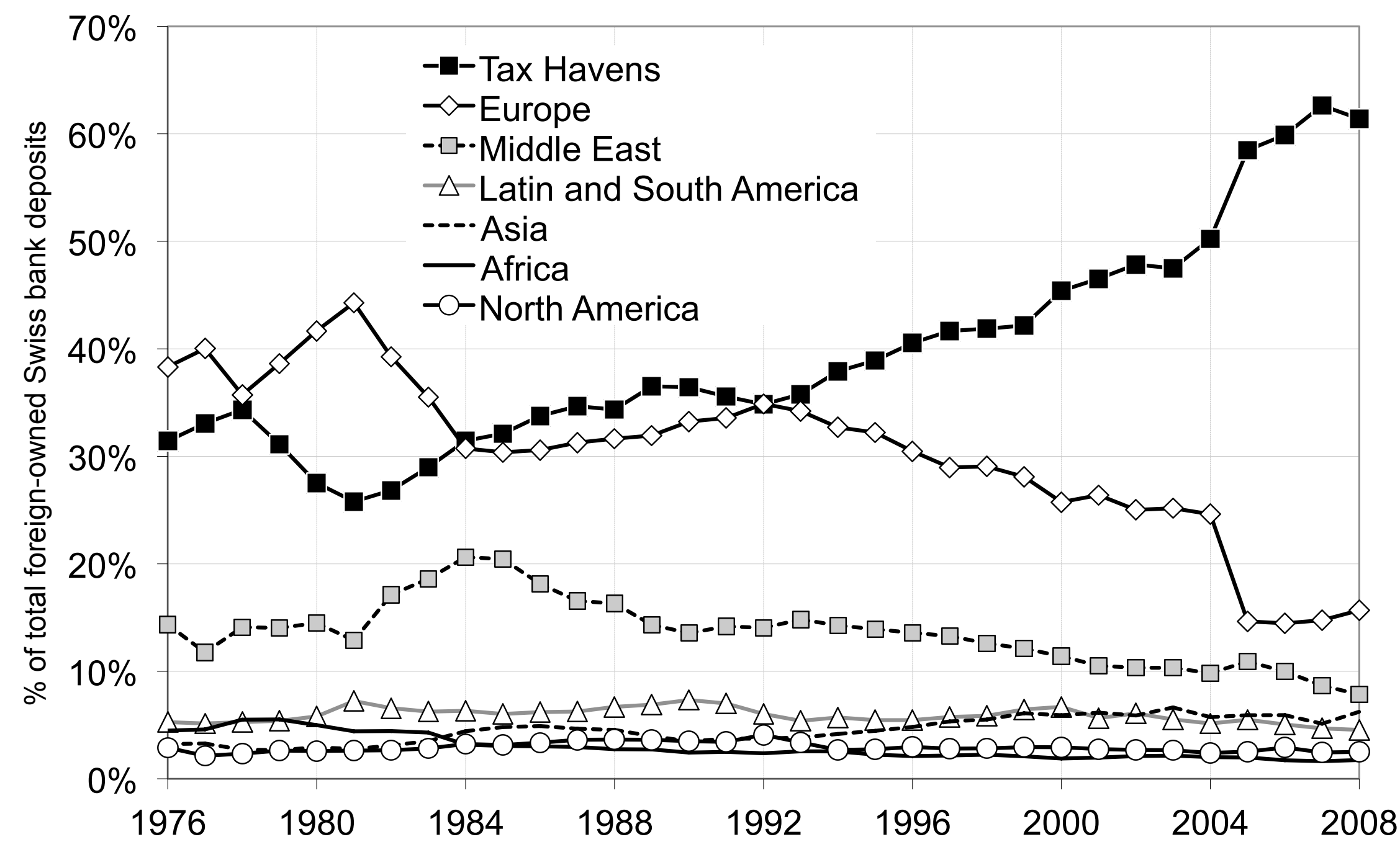

Note: This figure shows which countries' residents own Swiss fiduciary bank deposits, as reported by the Swiss National Bank (SNB). The SNB does not see through the sham corporations with addresses in such places as Panama or the British Virgin Islands used by European, U.S., and other rich countries' households as nominal owners of their accounts. This explains the high share of deposits assigned to tax havens.

Source: Appendix Table A25. 
Figure IV: Each Year, Less Securities Assets Are Recorded Than Liabilities

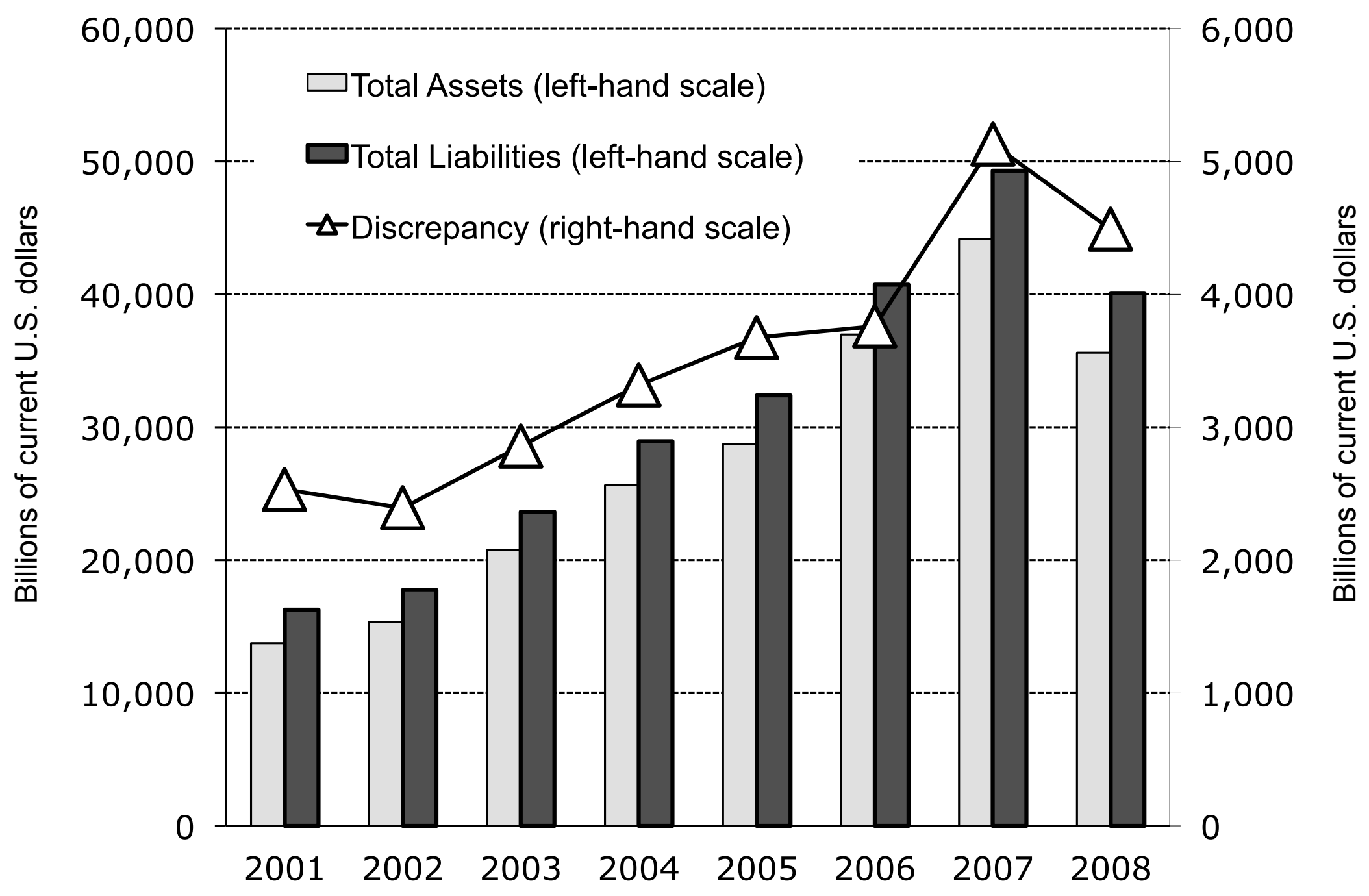

Note: This figure charts the securities assets and liabilities identifiable worldwide. Securities include all equities and bonds classified as portfolio investments or reserves. The totals cover 237 countries and territories along with international organizations.

Source: Appendix Table A3. 
Figure V: Each Year, Less Equity Assets Are Recorded Than Liabilities

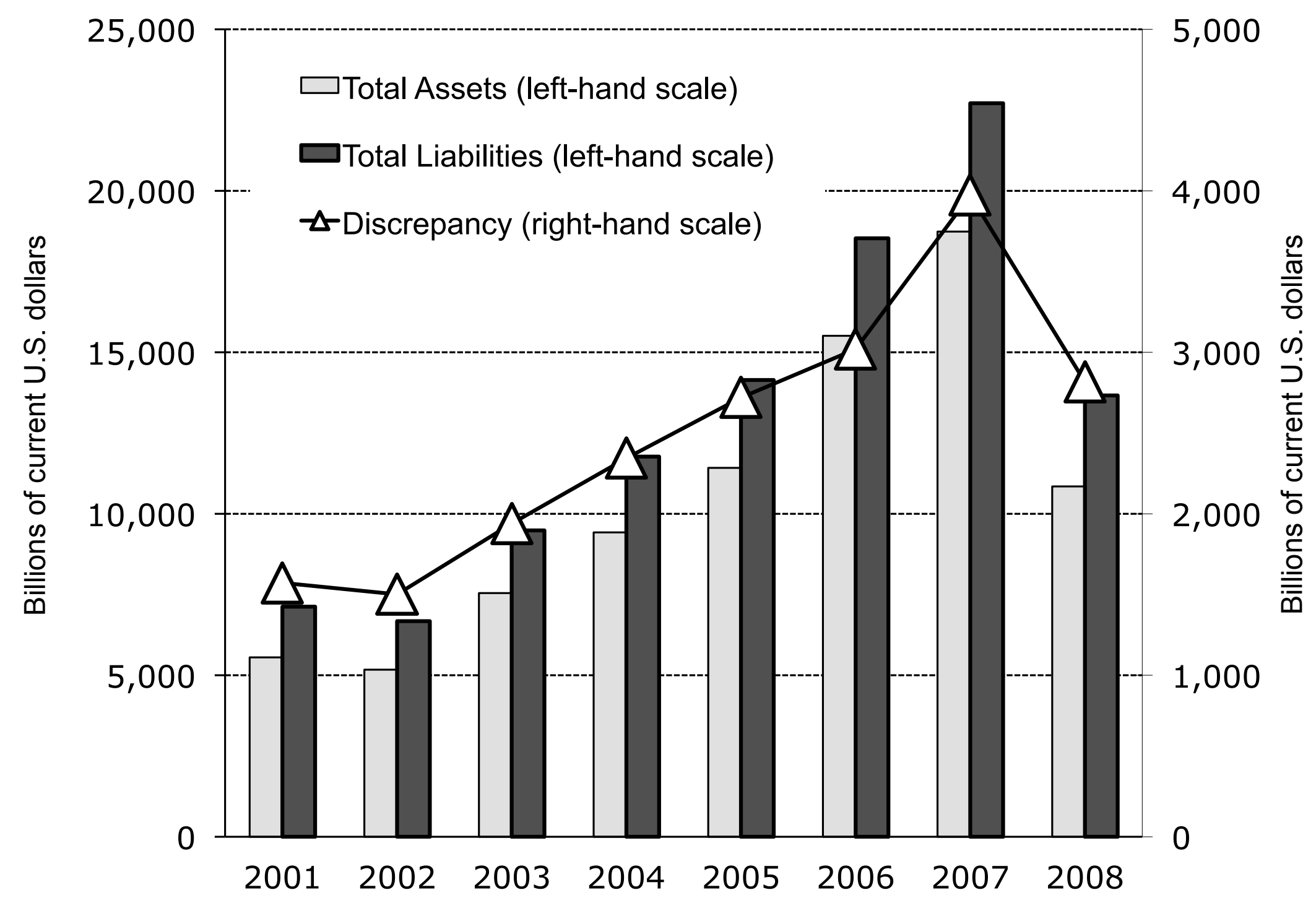

Note: This figure charts the equity assets and liabilities identifiable worldwide. Equities include all equities classified as portfolio investments or reserves. The totals cover 237 countries and territories along with international organizations.

Source: Appendix Table A3. 
Figure VI: Each Year, Less Bond Assets Are Recorded Than Liabilities

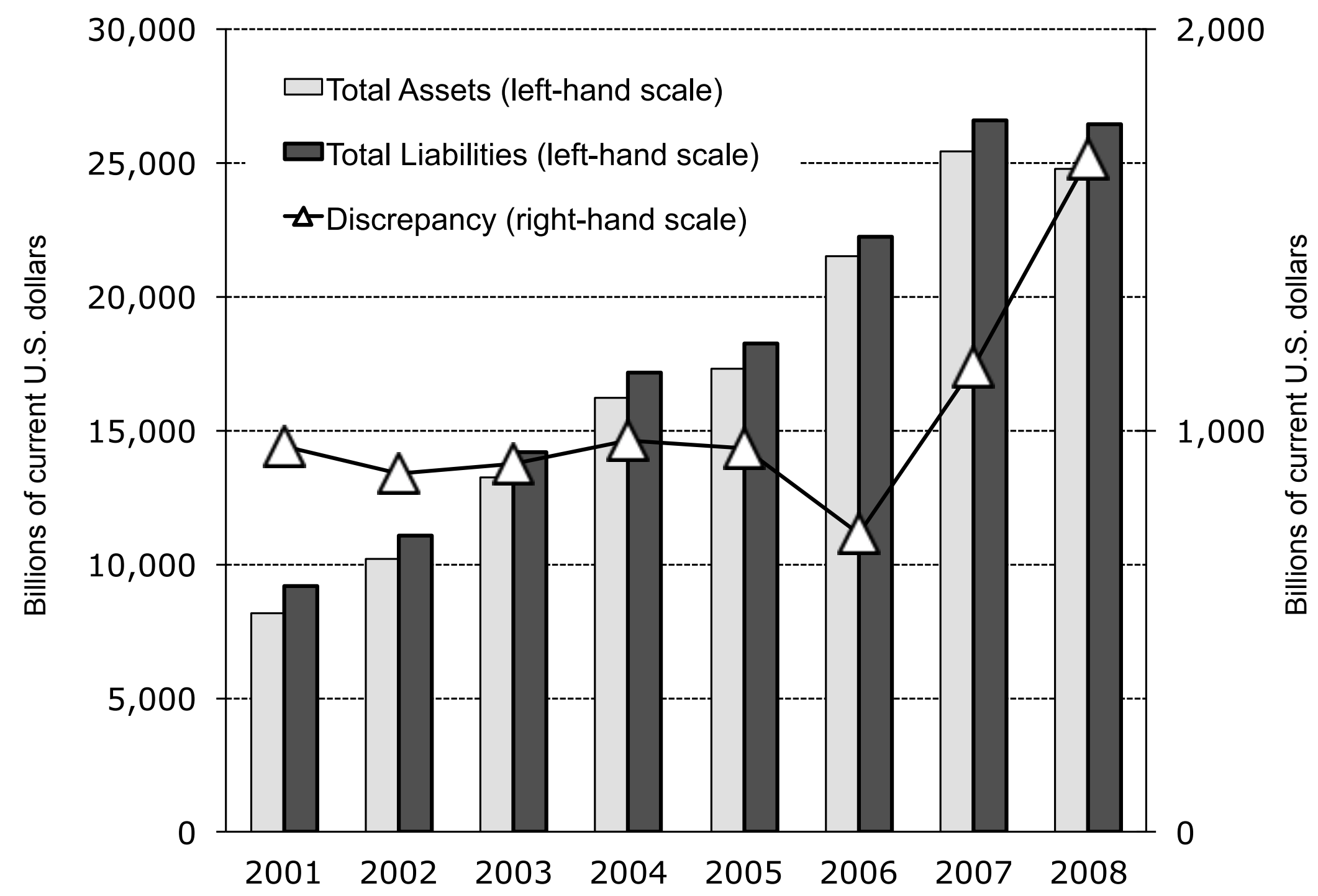

Note: This figure charts the bond assets and liabilities identifiable worldwide. Bonds include all debt securities classified as portfolio investments or reserves. The totals cover 237 countries and territories along with international organizations.

Source: Appendix Table A3. 
Figure VII: Many Mutual Fund Shares Have no Readily Identifiable Owners in the Official Statistics

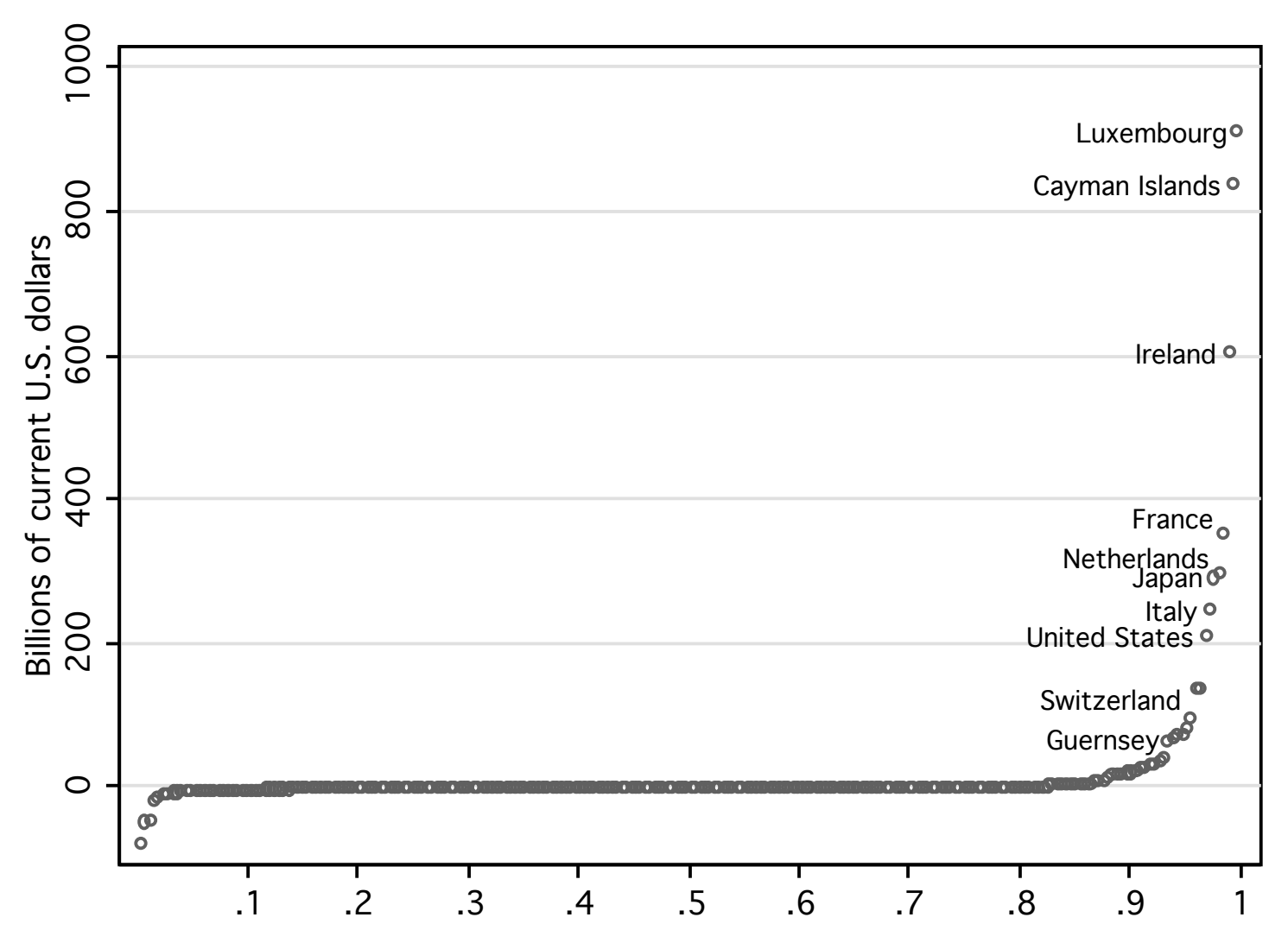

Note: Each dot represents a country $j$ and is equal to the difference between the securities liabilities reported in 2008 by $j\left(L_{j}\right)$ and the sum of the securities assets on $j$ held by 236 countries $i$ and international organizations $\left(\sum_{i} \hat{A}_{i j}\right)$. The securities issued by Luxembourg, the Cayman Islands, and Ireland, are mostly mutual fund shares.

Source: Appendix Tables A13 and A14. 
Figure VIII: The World Now Runs a Large Trade Surplus

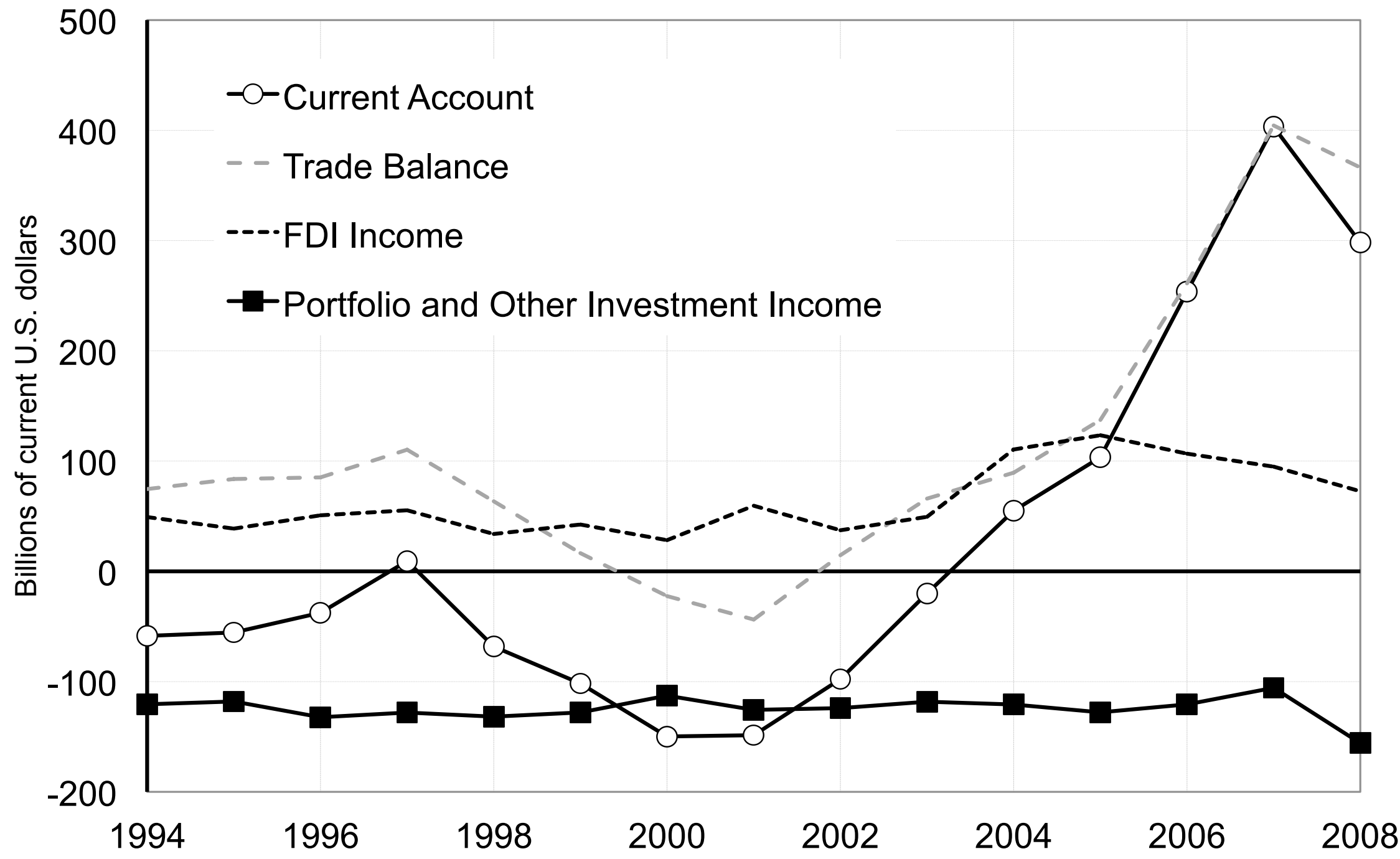

Note: This figure charts the statistical anomalies in the world's balance of payments, which includes data for all countries and territories. Each year, more portfolio and other investment income is paid than received, the flow counterpart of missing assets in international investment positions. Since 2004, the world has been running a large trade surplus, driving a large current account surplus.

Source: Appendix Table A21. 
Table I: Securities Form the Bulk of Cross-Border Wealth

(End of 2008 values)

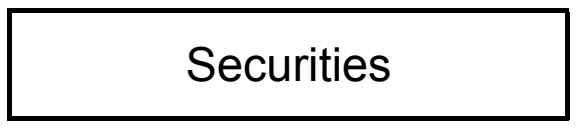

Bonds

Equities (including mutual fund shares)

FDI

Other (loans, deposits...)

Total cross-border wealth

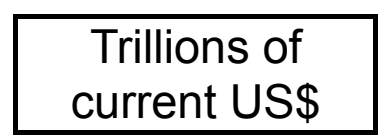

$\%$ of world GDP
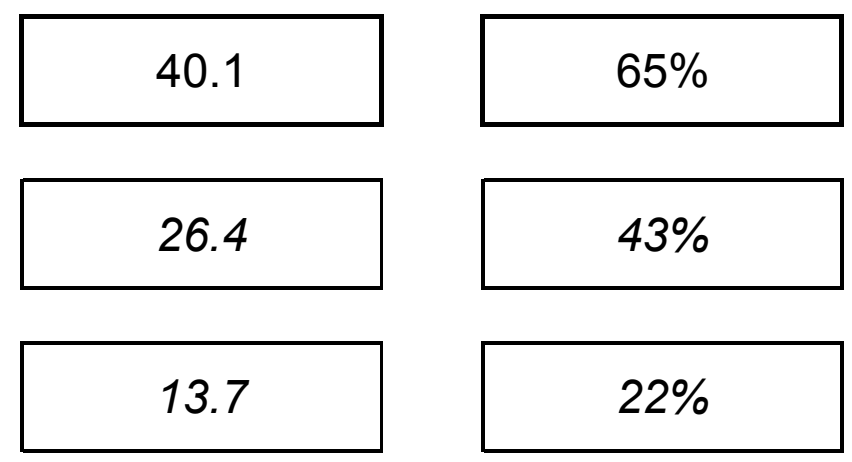

17.7

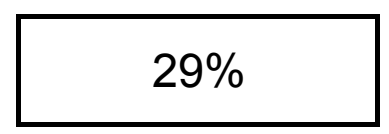

32.0

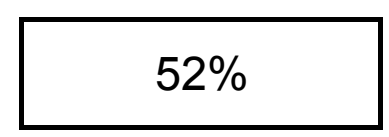

89.9

$146 \%$

\section{Memo: World GDP (2008) = US\$ 61.4tr}

Note: Securities include all "portfolio investments" and the fraction of "reserve assets" invested in equities and bonds. In international investment statistics, all mutual fund shares are classified as equities (irrespective of whether the funds invest in equities or bonds). FDI stands for foreign direct investment. Derivatives are excluded because they are not measured yet in all leading economies.

Source: IMF Balance of Payments Statistics and the updated and extended version of the External Wealth of Nations database constructed by Lane and Milesi-Ferretti (2007). 
Table II: Large Portfolios of Securities Are Held in Swiss Banks by Foreigners

(End of 2008 values in billions of current US\$)
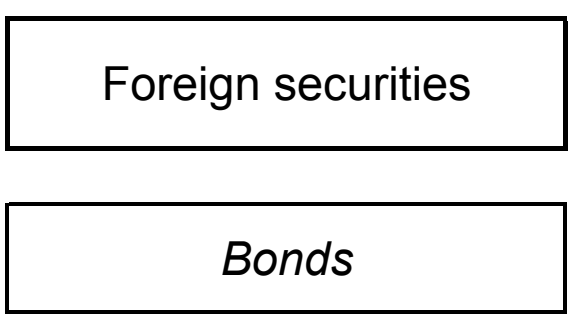

Equities

(Of which: mutual fund shares)

\section{Fiduciary bank deposits}

Total
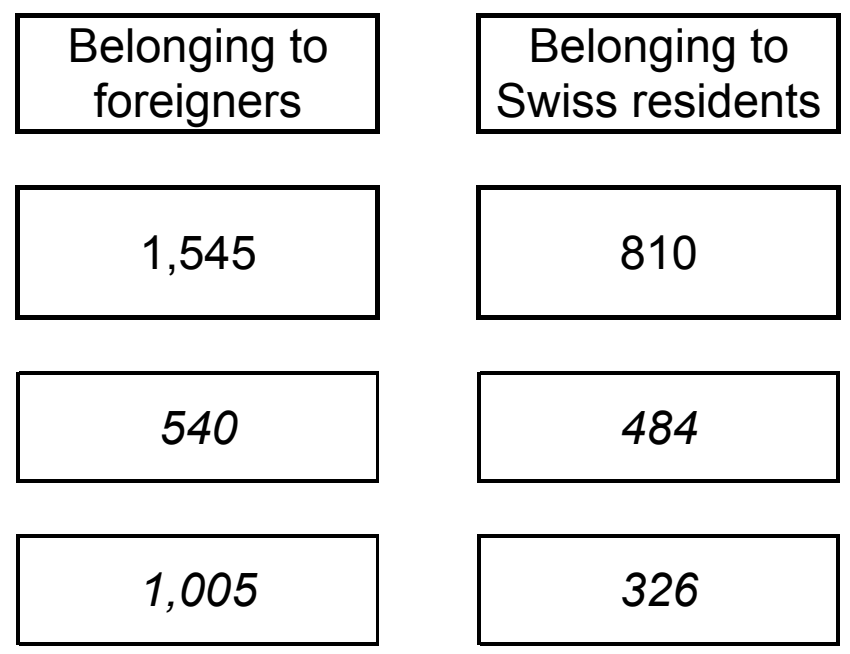

326

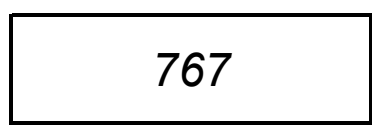

196
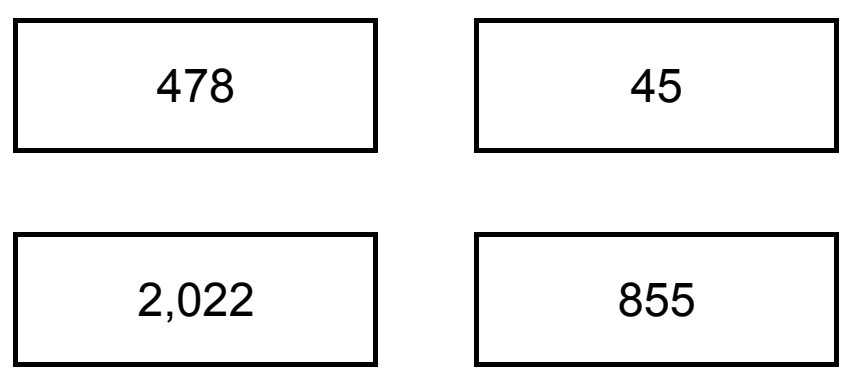

855

Source: Securities: Swiss National Bank's Monthly Statistical Bulletin (http: //www.snb.ch/en/iabout/stat/statpub/statmon/stats/statmon), series $D 5_{1}$, $D 5_{1 a}, D 5_{1}, D 5_{1 b}, D 5_{2}$ and $D 5_{2 b}$ and Banks in Switzerland (http://www.snb.ch/ en/iabout/stat/statpub/bchpub/stats/bankench), series 38a, 38b, 38c. Fiduciary deposits: Monthly Statistical Bulletin, series D4, D4 $4_{1 a}, D 4_{2 a}$, and Banks in Switzerland series 36, 37, 38. 


\section{Table III: Estimated Offshore Wealth, World and Switzerland}

(End of 2008 values in billions of current US\$)

Offshore securities

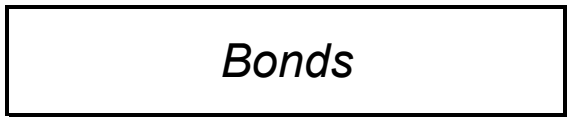

Equities

(Of which: mutual fund shares)

\section{Offshore bank deposits}

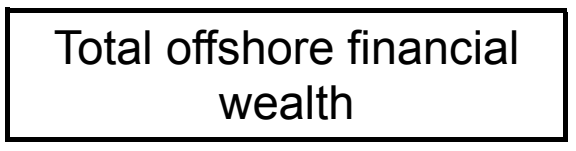

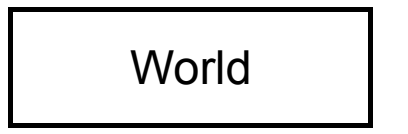
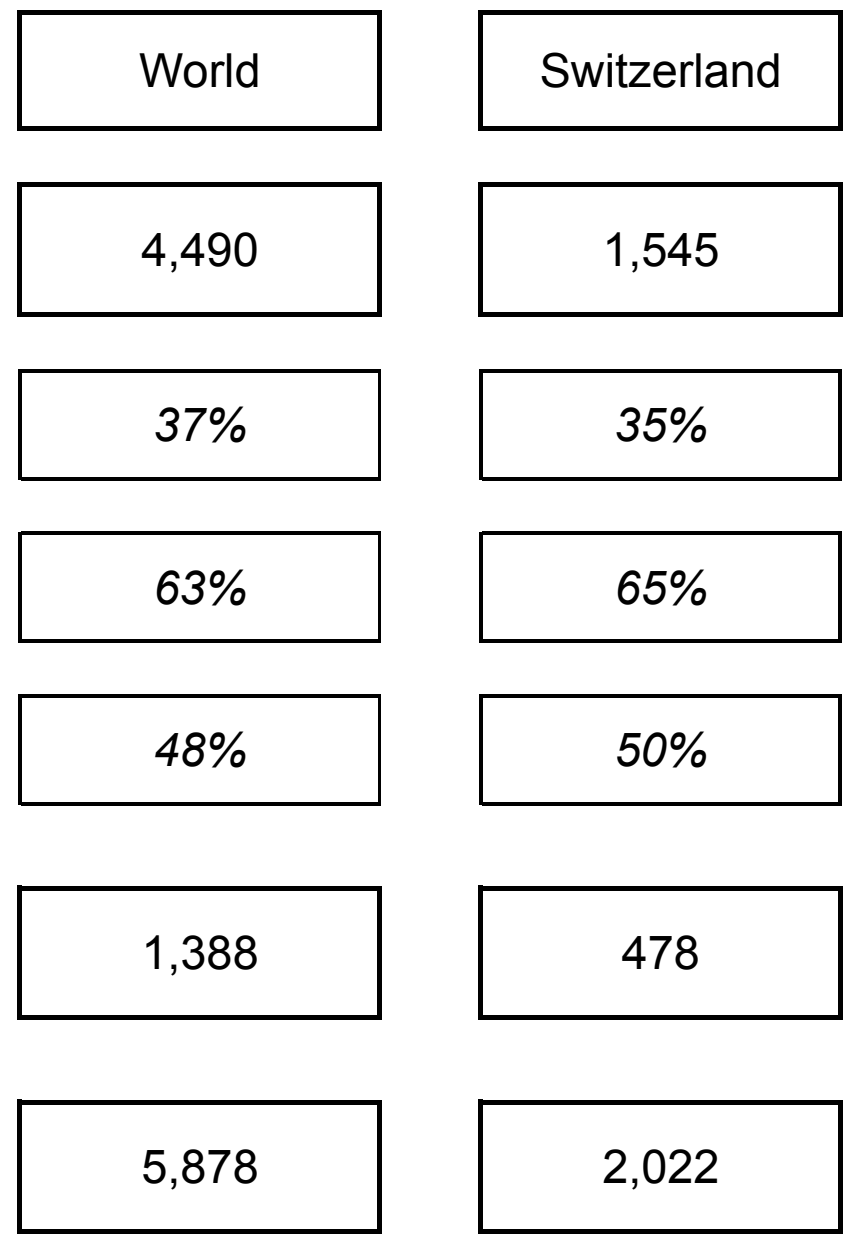

\section{Memo: Global household financial wealth $=73,625$}

Note: Global household financial wealth includes bank deposits, portfolios of securities, insurance contracts of households net of households' debt. Offshore financial wealth includes the bank deposits and portfolios of securities held by households in tax havens. It excludes real estate and other real assets held in tax havens.

Source: Offshore financial wealth: Appendix Tables A3, A23, and A24. Global household financial wealth: Credit Suisse (2010). 
Table IV: The Anomalies Caused by Unrecorded Assets Are Internally Consistent

\begin{tabular}{|c|c|c|c|c|c|c|c|c|c|}
\hline & & 2001 & 2002 & 2003 & 2004 & 2005 & 2006 & 2007 & 2008 \\
\hline [1] & Stock $(\Omega)$, bn $\$$ & 2,532 & 2,392 & 2,858 & 3,316 & 3,676 & 3,760 & 5,131 & 4,490 \\
\hline [2] & Inflows $(I)$, bn $\$$ & 38 & 164 & 153 & 240 & 230 & 116 & 189 & 364 \\
\hline [3] & Valuation (VAL), bn\$ & n.a. & -304 & 313 & 218 & 130 & -31 & 1,182 & $-1,006$ \\
\hline [4] & $\begin{array}{l}\text { Interest and } \\
\text { dividends }(D), \text { bn\$ }\end{array}$ & 126 & 124 & 118 & 121 & 128 & 121 & 106 & 156 \\
\hline [5] & Yield $\left(r_{\Omega}=D / \Omega\right)$ & $5.0 \%$ & $5.2 \%$ & $4.1 \%$ & $3.6 \%$ & $3.5 \%$ & $3.2 \%$ & $2.1 \%$ & $3.5 \%$ \\
\hline
\end{tabular}

Note: This table reports on the estimated stocks and flows of unrecorded portfolios. Inflows are the net purchases of securities from unrecorded accounts. Valuation denotes the net capital gains/losses on unrecorded portfolios. Interest and dividends are the income earned by the owners of unrecorded portfolios.

Source: Appendix Tables A3 and A21; IMF Balance of Payments Statistics 2010, Table C-1: "Global discrepancies in balance of payments statistics." 
Table V: Accounting for the Wealth in Tax Havens Can Turn the Eurozone Into a Net Creditor

\begin{tabular}{cccccc}
\hline & \multicolumn{5}{c}{$\begin{array}{c}\text { Share of offshore portfolios in Switzerland } \\
\text { belonging to eurozone residents }\end{array}$} \\
\cline { 2 - 6 } & $0 \%$ & $\mathbf{4 0 \%}$ & $\mathbf{5 0 \%}$ & $\mathbf{6 0 \%}$ \\
$\begin{array}{c}\text { Share of } \\
\text { offshore }\end{array}$ & $\mathbf{0 \%}$ & $-11 \%$ & $-6 \%$ & $-5 \%$ & $-3 \%$ \\
$\begin{array}{c}\text { portfolios in } \\
\text { other havens } \\
\text { belonging to } \\
\text { eurozone }\end{array}$ & $\mathbf{2 5 \%}$ & $-6 \%$ & $0 \%$ & $1 \%$ & $2 \%$ \\
\hline \begin{tabular}{c} 
residents \\
\hline
\end{tabular} & $\mathbf{7 5 \%}$ & $0 \%$ & $5 \%$ & $7 \%$ & $8 \%$ \\
\hline
\end{tabular}

Note: The Table reads as follows. The official eurozone's net foreign asset position/GDP ratio averaged $-11 \%$ over the 2001-2008 period. If eurozone residents owned $40 \%$ of the unrecorded assets held through Switzerland and $50 \%$ of those held through the other tax havens, the true net foreign asset position/GDP ratio of the eurozone averaged $+5 \%$.

Source: Appendix Table A28.

Table VI: Accounting for the Wealth in Tax Havens Improves the U.S. Net Foreign Asset Position

\begin{tabular}{ccccc}
\hline & \multicolumn{2}{c}{$\begin{array}{r}\text { Share of offshore portfolios in Switzerland } \\
\text { belonging to U.S. residents }\end{array}$} \\
\cline { 2 - 4 } & $0 \%$ & $\mathbf{5 \%}$ & $\mathbf{1 5 \%}$ \\
$\begin{array}{c}\text { Share of } \\
\text { offshore }\end{array}$ & $\mathbf{0 \%}$ & $-18 \%$ & $-17 \%$ & $-16 \%$ \\
$\begin{array}{c}\text { portfolios in } \\
\text { other havens } \\
\text { belonging to }\end{array}$ & $\mathbf{2 5 \%}$ & $-13 \%$ & $-13 \%$ & $-12 \%$ \\
$\begin{array}{c}\text { U.S. residents } \\
\text { b. }\end{array}$ & $\mathbf{7 5 \%}$ & $-9 \%$ & $-8 \%$ & $-7 \%$ \\
\end{tabular}

Note: The table reads as follows. The official U.S. net foreign asset position/GDP ratio averaged $-18 \%$ over the $2001-2008$ period. If U.S. residents owned $15 \%$ of the unrecorded assets held through Switzerland and 25\% of those held through the other tax havens, the true net foreign asset position/GDP ratio of the U.S. averaged $-12 \%$. Source: Appendix Table A29. 